\title{
The Rise and Decline of the American Ghetto
}

\section{Citation}

Cutler, David M., Edward L. Glaeser and Jacob L. Vigdor. 1999. The rise and decline of the American ghetto. Journal of Political Economy 107(3): 455-506.

\section{Published Version}

http://dx.doi.org/10.1086/250069

\section{Permanent link}

http://nrs.harvard.edu/urn-3:HUL.InstRepos:2770033

\section{Terms of Use}

This article was downloaded from Harvard University's DASH repository, and is made available under the terms and conditions applicable to Other Posted Material, as set forth at http:// nrs.harvard.edu/urn-3:HUL.InstRepos:dash.current.terms-of-use\#LAA

\section{Share Your Story}

The Harvard community has made this article openly available.

Please share how this access benefits you. Submit a story.

\section{Accessibility}




\section{The Rise and Decline of the American Ghetto}

\section{David M. Cutler and Edward L. Glaeser}

Harvard University and National Bureau of Economic Research

Jacob L. Vigdor

Harvard University

This paper examines segregation in American cities from 1890 to 1990 . From 1890 to 1940 , ghettos were born as blacks migrated to urban areas and cities developed vast expanses filled with almost entirely black housing. From 1940 to 1970 , black migration continued and the physical areas of the ghettos expanded. Since 1970, there has been a decline in segregation as blacks have moved into previously all-white areas of cities and suburbs. Across all these time periods there is a strong positive relation between urban population or density and segregation. Data on house prices and attitudes toward integration suggest that in the mid-twentieth century, segregation was a product of collective actions taken by whites to exclude blacks from their neighborhoods. By 1990, the legal barriers enforcing segregation had been replaced by decentralized racism, where whites pay more than blacks to live in predominantly white areas.

\section{Introduction}

Recent research has provided substantial evidence that who one's neighbors are affects one's economic and social outcomes. Case and

We are grateful to Joseph Geraci for truly exceptional research assistance; to Claudia Goldin, Larry Katz, Sherwin Rosen, Andrei Shleifer, and an anonymous referee for many helpful comments; and to the National Science Foundation and National Institutes on Aging for research support. All the data in this paper are available over the World Wide Web through online data at http://www.nber.org. 
Katz (1991) show that youths in a central city are affected by the characteristics of their neighbors. Borjas (1995) argues that ethnic and neighborhood effects are important in explaining outcomes. Cutler and Glaeser (1997) show that black outcomes in cities marked by higher black-white segregation are worse than black outcomes in less segregated cities. ${ }^{1}$ Since neighbors are so important in determining economic outcomes, it is important to understand how neighborhoods are formed. For the vast majority of blacks, the neighborhood has come to mean an area that is nearly exclusively black, which we refer to as a ghetto. In this paper, we examine the birth and development of ghettos in twentieth-century America.

Despite much research on segregation and racial tension (e.g., DuBois 1899; Myrdal 1944; Massey and Denton 1993) and despite the many excellent histories of individual ghettos that have been written (Glazer and Moynihan 1963; Osofsky 1966; Spear 1967; Kusmer 1976; Zunz 1982), there are no consistent long-term measures of the extent of ghettoization in the United States. ${ }^{2}$ Our first goal in this paper is to document changes in racial segregation in the United States over time. We present uniform, consistent measures of segregation from 1890 to 1990 , with sample sizes ranging from 54 cities in 1900 to 313 metropolitan statistical areas (MSAs) today.

The data suggest a division of the history of segregation into three periods. The first period, from 1890 to 1940, saw the birth of the ghetto, accompanied by and perhaps due to the first large-scale black migration from the rural South to the urban North. The changes in urban residential location were quite dramatic. Where only one city had a ghetto by our definition in 1890 (Norfolk, Va.), 55 cities had a ghetto by 1940 . In 1890 , the average urban black lived in a neighborhood that was 27 percent black; by 1940, that neighborhood was 43 percent black. During the second period, from 1940 to 1970 , ghettos consolidated and expanded. With continuing black migration to urban areas and increased racial tensions, ghettos came to dominate the central city. The peak period for segregation in the United States was 1970. In that year, the average black in urban America lived in a neighborhood that was 68 percent black. In the third period, from 1970 to 1990, segregation fell throughout the country, particularly in the rapidly growing cities of the South and West. By 1990, the average black lived in a neighborhood that was 56 percent black.

\footnotetext{
1 Other work investigates the relation between poverty and segregation, including Korenman, Sjaastad, and Jargowsky (1995), Yinger (1995), and O'Regan and Quigley (1996).

${ }^{2}$ Lieberson (1980) has the most complete data. Ellen (1996) presents an excellent discussion of the path of segregation since 1970.
} 
While segregation has changed dramatically over the past century, the relative segregation of different cities has been much more persistent. The correlation across cities between segregation in 1890 and segregation in $\mathbf{1 9 9 0}$ is as high as $\mathbf{5 0}$ percent. Of the five most segregated cities in the United States in 1890, three are in the top five today (Chicago, Cleveland, and Detroit).

In the second part of the paper, we consider why this pattern of segregation developed and perpetuated itself. We group theories about segregation into three classes: the "port of entry" theory, where blacks prefer to live among members of their own race, particularly when they are new migrants to an urban area; the "centralized" or "collective action racism" theory, where whites use legral, quasi-legal, or violent, illegal barriers to keep blacks out of white neighborhoods; and the "decentralized racism" theory, where whites segregate themselves by paying more to live with members of their own race. ${ }^{3}$

All three theories predict that segregation should change rapidly with the influx of new migrants to a city, and this is true empirically. The theories also suggest that segregation should rise as the number of neighborhoods rises and possibly as people become more mobile. We find that larger cities do have greater levels of segregation than smaller cities, but we find no significant evidence that segregation is related to transportation costs.

To differentiate among the three theories, we use two types of evidence: information on housing costs and attitudes toward integration. If whites and blacks are segregated because blacks who are recent migrants prefer segregated neighborhoods or because whites make it impossible for blacks to live in integrated neighborhoods, then blacks should pay more for equivalent housing than whites. In contrast, if blacks and whites are segregated because whites demand housing in white areas more than blacks demand housing in those areas, then whites should pay more for housing than blacks.

We find that at the middle of the century, blacks paid relatively more for housing in segregated cities than in integrated cities, but new migrants paid no more than long-term residents. These facts suggest that at midcentury, segregation was enforced by collective actions on the part of whites to limit the access of blacks to white neighborhoods. By 1990, however, whites pay more for equivalent housing than blacks in more segregated metropolitan areas, suggesting that decentralized racism has replaced centralized racism as

${ }^{3}$ For our purposes, racism does not connote a belief in the inherent supericitity or inferiority of a racial group. Rather, it pertains to individual tastes for a particular type of neighborhood racial composition. 
the factor influencing residential location. This evidence is generally consistent with attitudes toward integration among blacks and whites over the past 20 years.

Section II introduces our measures of segregation. Section III discusses the data and presents the time series of segregation in the United States. Section IV examines differences in segregation across cities. Section V considers alternative theories for the formation and persistence of ghettos, and Section VI tests those theories. Section VII presents three case studies of segregation in particular cities, and Section VIII presents conclusions.

\section{Measuring Segregation}

There are many dimensions to the spatial segregation of different racial groups. We focus on two measures of segregation. ${ }^{4} \mathrm{~A}$ first dimension of segregation is the dissimilarity of black and white residences. If blacks disproportionately reside in some areas of a city relative to whites, we say that dissimilarity between the two races is high. The index of dissimilarity, proposed by Duncan and Duncan (1955) and used by Taeuber and Taeuber (1965), is a natural measure of dissimilarity:

$$
\text { index of dissimilarity }=1 / 2 \sum_{i=1}^{N}\left|\frac{\text { black }_{i}}{\text { black }_{\text {total }}}-\frac{\text { nonblack }_{i}}{\text { nonblack }_{\text {total }}}\right| \text {, }
$$

${\text { where } \text { black }_{i} \text { is the number of blacks in area } i \text {, black }}_{\text {total }}$ is the number of blacks in the city as a whole, nonblack ${ }_{i}$ is the number of nonblacks in area $i$, and nonblack total $_{1}$ is the number of nonblacks in the city. This index ranges from zero to one and can be shown to answer the following question: What share of the black (or white) population would need to change areas for the races to be evenly distributed within a city? Typically, a dissimilarity index of less than .3 is considered low, an index between .3 and .6 is considered moderate, and an index above .6 is considered high (Massey and Denton 1993).

But even if blacks are disproportionately located in particular neighborhoods relative to whites, that does not mean that blacks and whites have little or no contact (Blau 1977). In measuring the isolation of blacks from whites, we want to measure the exposure of blacks to whites. To measure isolation, we follow Bell (1954) and start with the percentage black of the area occupied by the average

\footnotetext{
${ }^{4}$ See Taeuber and Taeuber (1965) and Massey and Denton (1988a) for a discussion. Glaeser and Scheinkman (1997) provide a theoretical analysis of this measure and other indices.
} 
black or $\sum_{i=1}^{N}\left(\right.$ black $_{i} /$ black $\left._{\text {toal }}\right) \cdot\left(\right.$ black $_{i} /$ persons $\left._{i}\right)$, where persons w $_{i}$ refers to the total population of tract $i$. To eliminate the effect coming from the overall size of the black population, we subtract from this the percentage black in the city as a whole. When there are low numbers of blacks in the city, it will be impossible for blacks to be completely isolated from whites; the maximum value of this measure is $\min \left(\right.$ black $_{\text {total }} /$ persons $\left._{i}, 1\right)-\left(\right.$ black $_{\text {total }} /$ persons $\left._{\text {total }}\right)$, where persons $_{i}$ is the size of the minimum population area. ${ }^{5}$ We divide our index by this maximum value so that the adjusted index ranges from zero to one:

$$
\text { index of isolation }=\frac{\sum_{i=1}^{N}\left(\frac{\text { black }_{i}}{\text { black }_{\text {toat }}} \cdot \frac{\text { black }_{i}}{\text { persons }_{i}}\right)-\left(\frac{\text { black }_{\text {toat }}}{\text { persons }_{\text {total }}}\right)}{\min \left(\frac{\text { black }_{\text {toal }}}{\text { persons }_{i}}, 1\right)-\left(\frac{\text { black }_{\text {total }}}{\text { persons }_{\text {toual }}}\right)} .
$$

As a summary measure, we characterize a city as having a ghetto if the index of dissimilarity is greater than .6 and the index of isolation is greater than .3 .

Dissimilarity and isolation are not the only potential measures of spatial concentration. Massey and Denton (1988a) characterize segregation along five dimensions: evenness (dissimilarity), exposure (isolation), concentration (the amount of physical space occupied by the minority group), clustering (the extent to which minority neighborhoods abut one another), and centralization (proximity to the center of the city). The last three dimensions require detailed data on physical location of areas and land size that we do not have for all years. We have constructed all five measures of segregation in 1990, which were reported in an earlier version of this paper (Cutler, Glaeser, and Vigdor 1997). Dissimilarity, isolation, and clustering are all highly correlated (correlation coefficients over .72). Concentration and, particularly, centralization are less highly correlated with the other measures. These results suggest that by 1990 at least, ghettos were relatively contiguous areas mainly occupied by blacks, but they did not have uniform sizes or locations within the city.

\section{Segregation in the Past Century}

We begin our analysis of the history of segregation with 1890 because that year predates the first wave of large black migration from the

\footnotetext{
${ }^{5}$ White (1986) suggests always dividing by one minus the black share in the city's population. Our two measures are identical for most modern cities, but in a city with very few blacks we believe that our measure should be more accurate.
} 
South to the urban North. Segregation in 1890 gives us a snapshot of what racial integration was like when whites in vast parts of the country had relatively little contact with blacks.

Data on segregation are based on information in the decadal censuses. The censuses are the only source of long-term subcity data on neighborhood characteristics. Not surprisingly, the Census Bureau has changed its methods and definitions over the past century. Thus ensuring comparability throughout the entire time period is difficult. We describe our data collection and adjustments extensively in Appendix B and give just a brief summary of our methods here. Because segregation measures are most meaningful when the black population is sizable, we sample only cities or MSAs with at least 1,000 blacks. Our sample size ranges from a low of 54 cities in 1900 to a high of 313 MSAs in 1990.

In the post-World War II censuses, we proxy for neighborhoods with census tracts, the most common measure of intracity spatial distribution. A census tract is an area of roughly 4,000 people separated by observable boundaries such as rivers, highways, or major streets. In most cities, census tracts were not delineated until 1940 or 1950. Prior to then, the census reported population at the ward level. Wards are political jurisdictions made up by the city for uses such as city governance. A ward typically had many more people than a census tract does now. As neighborhoods are combined, both measures of segregation will fall (proof available on request). Thus ward-based segregation measures are below tract-based measures. We adjust the ward data to match the mean of the census tract data, so that changes in the size of neighborhood units will not affect our measures of the trend of segregation over time (see App. B).

The ward data are of some concern if wards are drawn to minimize or maximize segregation. Fortunately, the census reported both ward and tract data for many cities in 1940, so we can measure the correlation between the two. For the Northeast and Midwest, that correlation is high ( .82 for dissimilarity in the Northeast $[N=19]$ and .81 for the Midwest $[N=16]$ ), giving us confidence in wardbased segregation for those regions. We also constructed tract-level measures of segregation in Cleveland going back to 1910; tractbased segregation moved closely with ward-based segregation. For southern cities, however, the correlation between tract- and wardbased dissimilarity is lower $(.59[N=11]$, or .35 with one outlier removed). Indeed, case studies of particular cities such as Atlanta suggest that ward-based segregation may significantly understate the true degree of segregation at the subward level. ${ }^{6}$ Thus we have less

${ }^{6}$ Atlanta in 1890 had many nearly exclusively black areas. These areas were distributed throughout the city, however. Thus, at the ward level, Atlanta appears to be 
confidence in pre-World War II segregation in the South than in the Northeast or Midwest. ${ }^{\text {? }}$

Before 1940, we measure segregation for cities, the standard political units. After World War II, wide-scale suburbanization led the Census Bureau to delineate multicounty metropolitan areas, MS $A$, which include both cities and their surrounding suburbs. ${ }^{8}$ Since we would like to measure segregation for an economic unit, we use MSAs when available. The relatively low level of suburbanization during the pre-1940 period makes us comfortable with our city-level data in the years in which MSA-level indices are impossible to construct. None of our results are driven by the change from city-level segregation indices to MSA-level indices, as we show below.

Figures 1 and 2 show the indices of dissimilarity and isolation from 1890 to 1990 , and table 1 reports summary statistics for the two measures. We report four measures of segregation. The first measure, labeled all cities, is mean segregation using all cities with data that year. The second measure, labeled all cities-central city only, measures segregation using central-city data exclusively from 1960 onward. ${ }^{9}$ The third measure, labeled weighted, weights segregation in each city by the number of blacks that year, to reflect segregation for the typical urban black at the time. The fourth measure, labeled matched sample, adjusts for the changing composition of cities over time. We form this index from decade-to-decade changes in segregation for cities that have data at both the beginning and end of a decade. We cumulate these changes, normalizing the index to the all-city mean in 1990.

All our indices tell a similar story. In each case, there is a tripartite division of the history of segregation: from 1890 to 1940, segregation rose dramatically, to levels associated with the modern ghetto; from 1940 to 1970, segregation expanded or leveled off; and after 1970, segregation declined. The division at the year 1970 is obvious: after this year, segregation began its decline. The break at the year 1940 is less clear. We choose to use 1940 as a dividing year because 1940 is the first year in which more than one-half of the cities in our

very integrated, but at a finer geographic unit, the city is quite segregated. See Kellogg (1977) for a discussion.

${ }^{7}$ The switch from ward to tract data in 1940 may be responsible for some of the observed increase in segregation in the South between 1930 and 1940. As discussed above, ward-based measures of segregation appear less reliable in the South.

${ }^{8}$ More precisely, the Census Bureau defined standard metropolitan statistical areas in the postwar period. In 1990, the Census Bureau changed the name of these areas to metropolitan statistical areas, and we adopt the latest nomenclature to refer to these multicounty units for the entire period.

${ }^{9}$ Because the census tract data in 1970 do not indicate whether a tract is inside or outside of a central city, the 1970 values are interpolated from 1960 and 1980 data. 


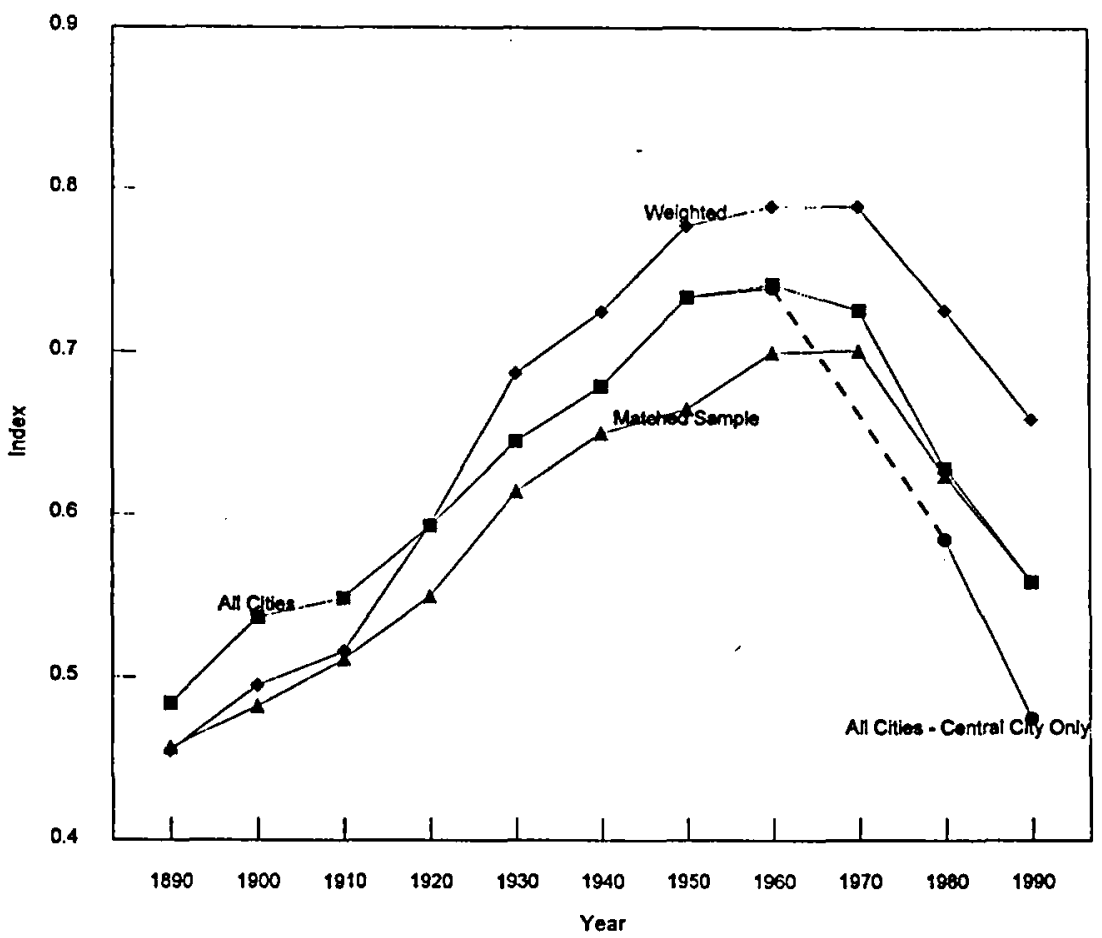

FIG. 1.-Index of dissimilarity, 1890-1990. Matched sample segregation is normalized to unmatched mean in 1990 . The 1970 value for central city only segregation is interpolated from 1960 and 1980.

sample had a ghetto, and many black ghettos were still being formed in the 1930s. But we acknowledge that this division is somewhat artificial, and 1930 or 1950 could also have been used as reasonable break points.

\section{The Birth of the Ghetto}

In 1890, American cities were segregated but not exceptionally segregated. While blacks were disproportionately concentrated in particular parts of cities (dissimilarity was 49 percent), these areas were not entirely or even mainly black. The average black lived in a ward that was only 27 percent black, and isolation was only 21 percent. Accounts of cities at this time frequently highlight the interactions between blacks and whites in everyday life (Spear 1967; Kusmer 1976). The spatial proximity of the races most distinguishes the city of 1890 from the city of today. While 11 cities had a dissimilarity index in the very high range (above .6) in 1890, only one city (Nor- 


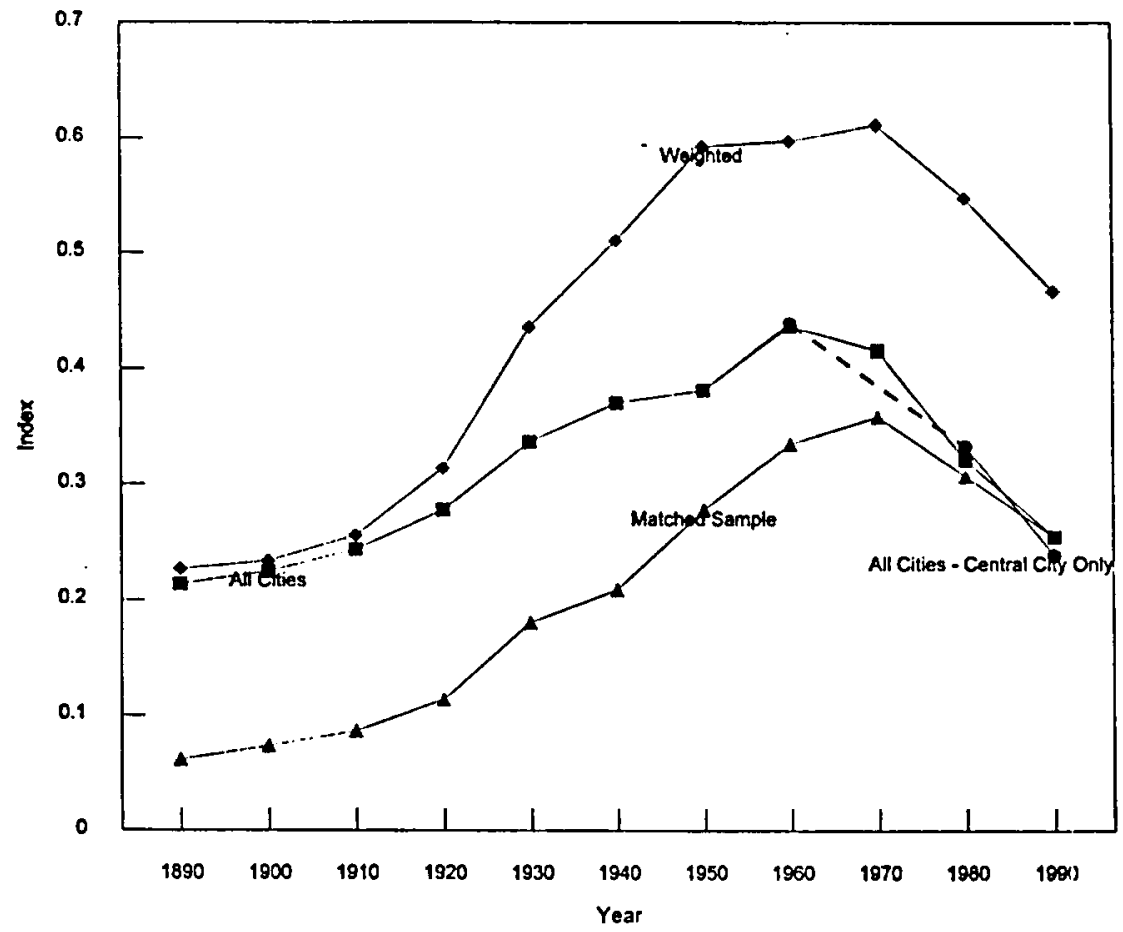

Fic. 2.-Index of isolation, 1890-1990. Matched sample segregation is nornalized to unmatched mean in 1990 . The 1970 value for central city only segregation is interpolated from 1960 and 1980.

folk, Va.) had blacks sufficiently isolated from whites (above .3) to say that there was a ghetto.

Even in 1890, however, there was a clear regional and city size pattern to segregation, as shown in figures 3 and 4 . Large cities in the Northeast and Midwest were the most segregated (even though only 2.5 percent of their population, on average, was black). Smaller cities, and cities in the South and West, were less segregated. These regional and size patterns persist largely intact over the next century.

Particularly during and after World War I, blacks came to the North from the rural South in record numbers. In part, migration was a result of heavy demand for labor in burgeoning industrial cities of the North, particularly during the two world wars, coupled with restrictions on immigration. Additionally, agricultural changes such as the automatic cotton picker drove black migration from the South of the Jim Crow era into the more comfortable social milieu of the North (see, e.g., Drake and Cayton 1945; Lemann 1991). Between 


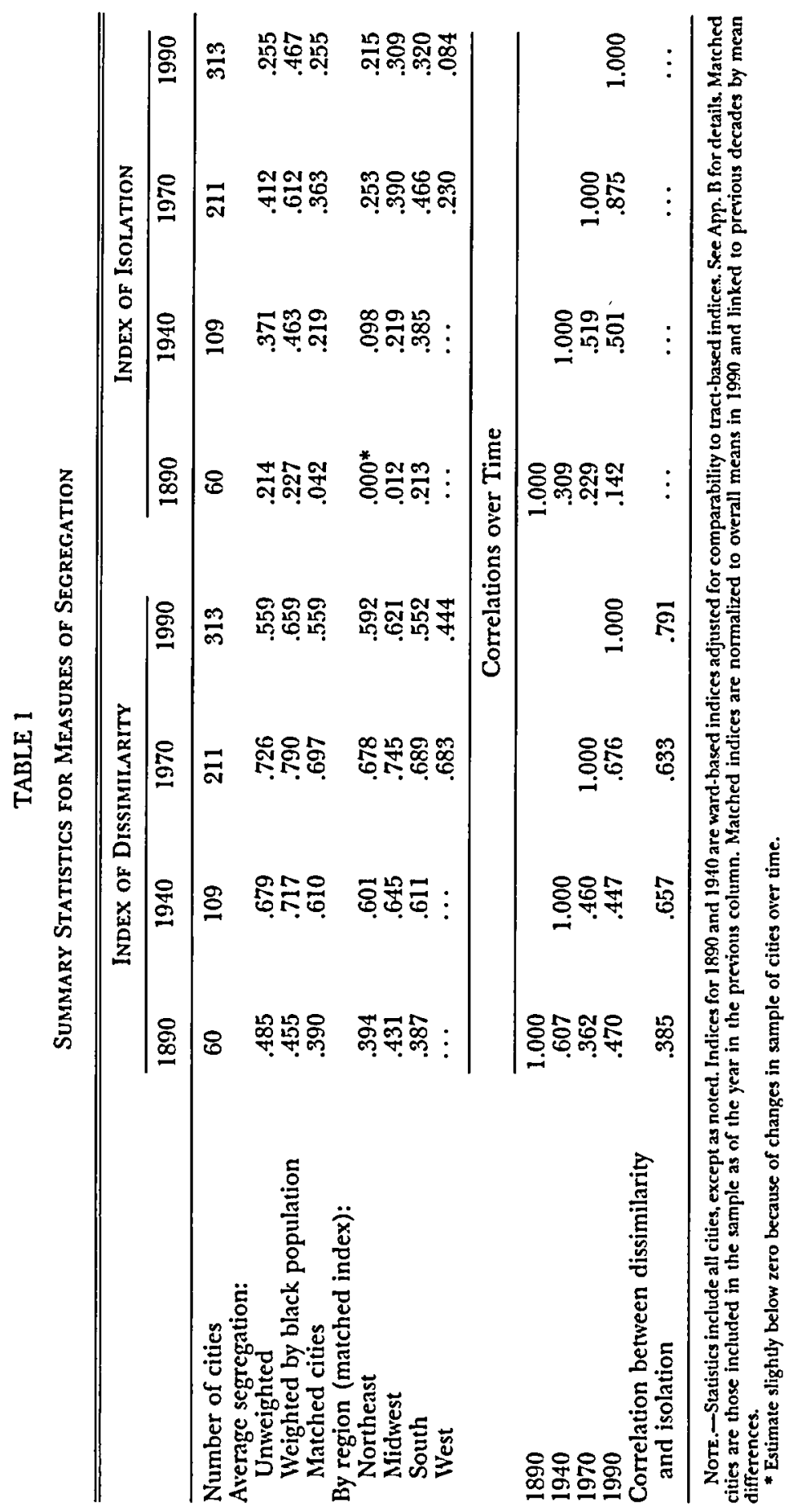




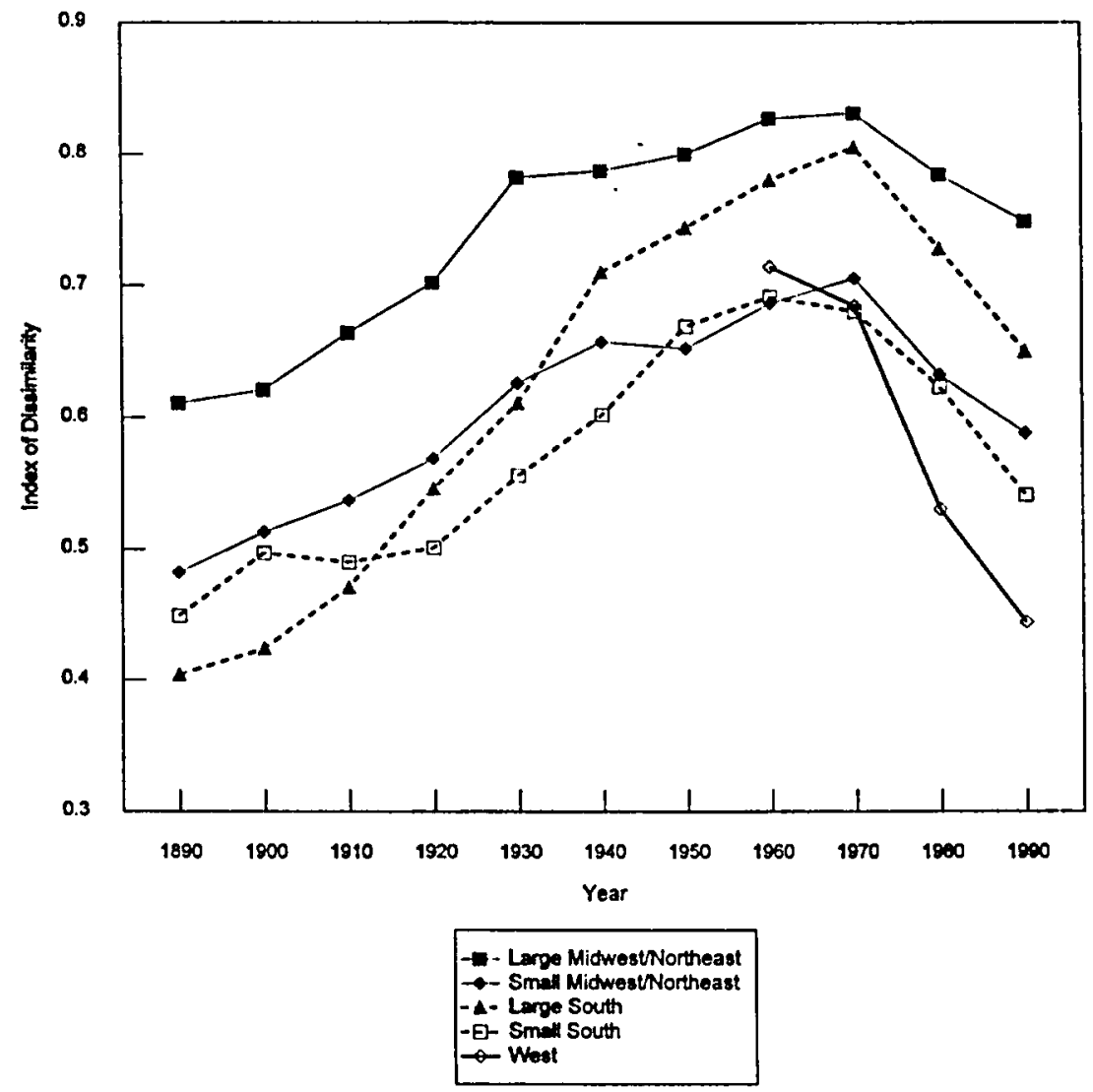

FIG. 3.-Dissimilarity by region and city size

1890 and 1940 the urban black population grew by about 4 percent annually in the Northeast and Midwest and about 2 percent annually in the South and West (see table 2). For many northern cities, this was the first experience with large black populations.

Segregation rose dramatically with the influx of southern blacks, particularly in the industrial North. Between 1890 and 1940, dissirnilarity rose by 20 percentage points (to 68 percent) and isolation increased by 15 percentage points (to 37 percent). For the first time, many cities saw the creation of entirely black areas. Where one city had a ghetto (dissimilarity above .6, isolation above .3) in 1890,55 cities had a ghetto in 1940. This includes essentially all the major industrial centers of the North. Segregation also increased in the South, although, as we noted above, we have less confidence in this conclusion than we do for the rise of segregation in the North. To 


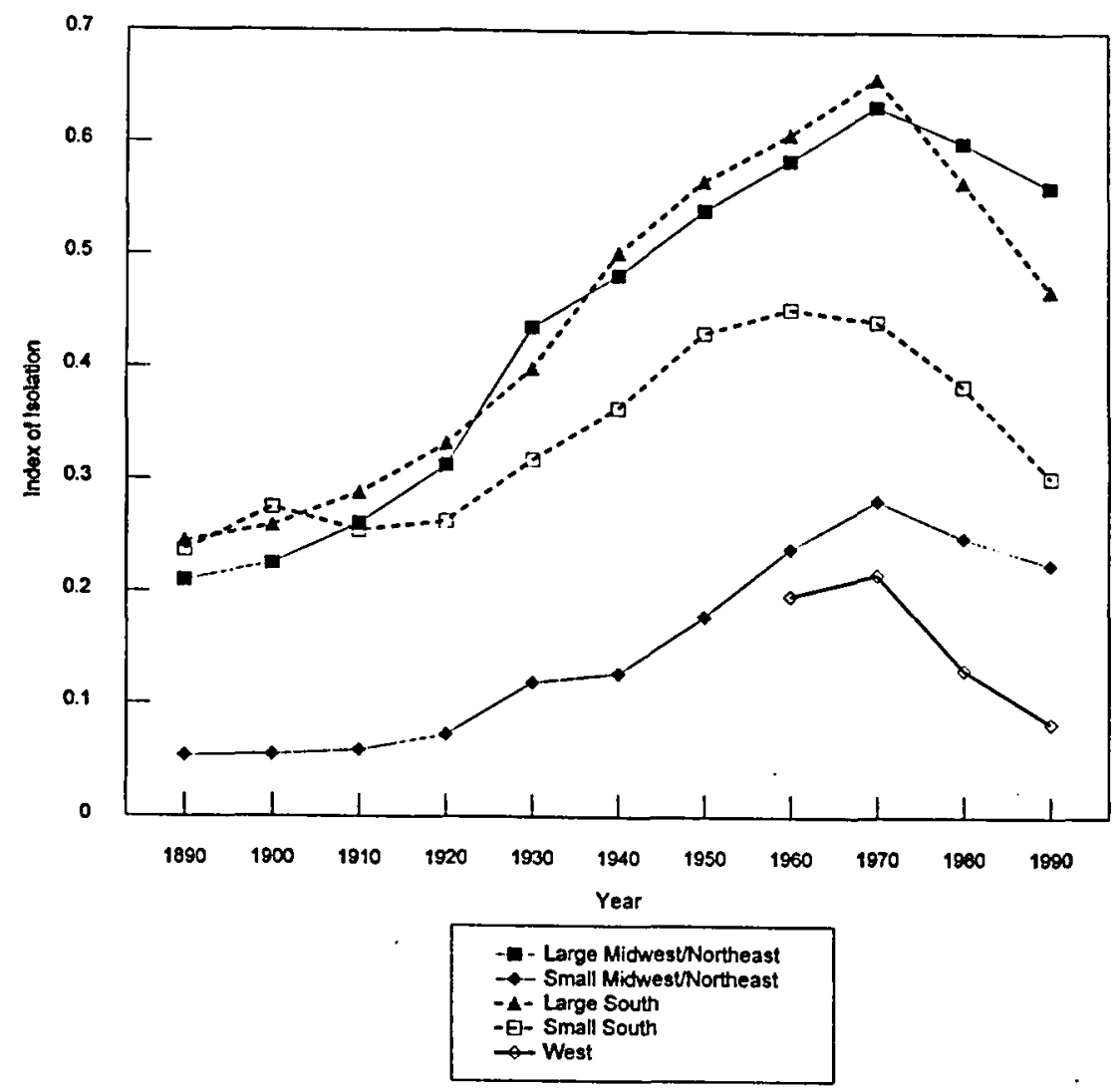

FIG. 4.-Isolation by region and city size

a great extent, the modern spatial distribution of races in American cities was established by 1940 .

To look at the relation between the great migration north and the rise of segregation, table 3 shows regressions for the change in segregation across cities from 1910 to 1940 as a function of the increase in the black population between those years, the increase in the nonblack population, a dummy variable for cities that had a high level of segregation to begin with, and that dummy variable interacted with the change in black population. ${ }^{10} \mathrm{We}$ include the last two terms because one would expect segregation in cities that were ini-

${ }^{10}$ We use data from 1910 because we have more cities in that year than in 1890 . The results are similar when 1890 is used as the starting year. Summary statistics for the data used in all the regressions are in App. table A3. 


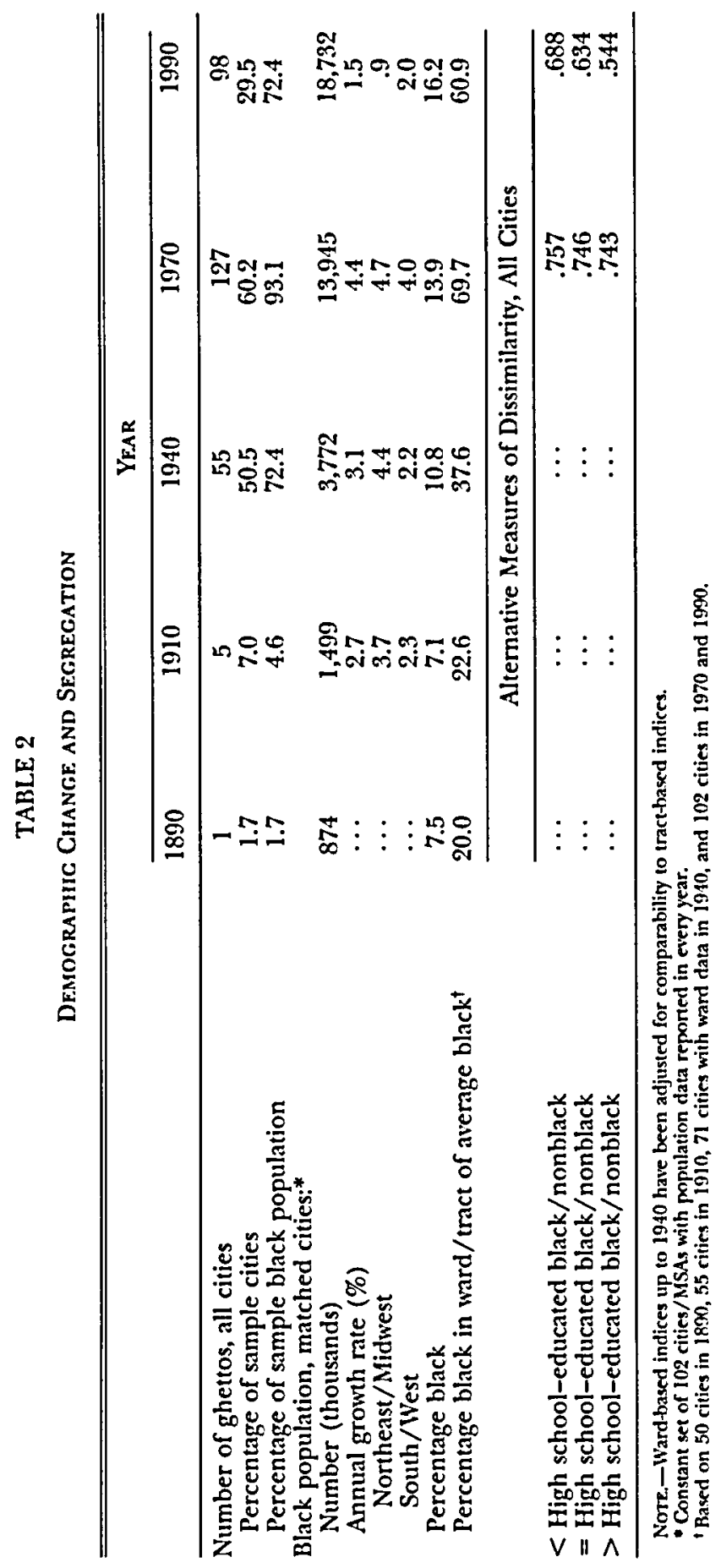




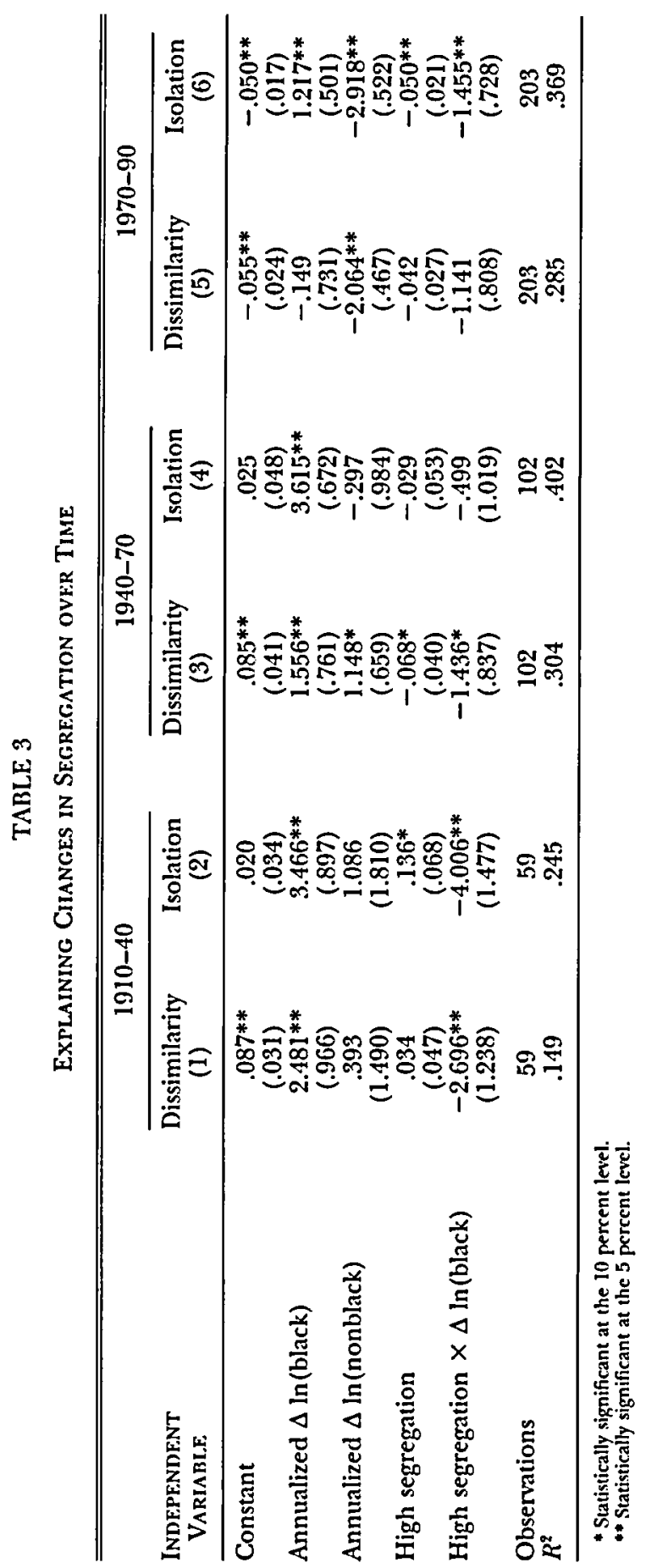

Copyright $\odot 1999$. All rights reserved. 
tially highly segregated to rise less rapidly and be less sensitive to changes in black population than cities that began less segregated.

Across cities, the growth of the ghetto is strongly and significantly related to the migration of blacks. An increase in the growth rate of the black population by four percentage points annually (roughly the average level in the North) leads to a change in dissimilarity of 16 percentage points and a change in isolation of 20 percentagre points. This is not just a growing city effect; growth of the nonblack population is not significantly associated with increases in segregation.

Over this same period, we find that segregation between the nativeborn and the foreign-born rose with the large inflows of immigration between 1890 and 1910, and then declined when immigration tapered (see Cutler et al. 1999). We therefore believe that the rise in segregation is not an artificial result created by changing geographic definitions during this period, but a true phenomenon of urban change.

\section{The Expanding Ghetto}

The early post-World War II period witnessed the second wave of migration of blacks from the rural South to the North. The number of migrants in the 1950s and 1960s was even greater than the nuinber after World War I; between 1940 and 1970, the black population grew 4.7 percent annually in northeastern and midwestern cities and 4 percent annually in the South and West (table 2).

The result was another large increase in segregation. Between 1940 and 1970, dissimilarity increased by five percentage points. Isolation increased by four percentage points in the all-city sample and 15 percentage points in the matched sample. As figures 3 and 4 show, the increase in segregation is particularly great in the large industrial cities of the Northeast and Midwest. Large southern cities also saw a dramatic increase in segregation in this period.

In addition to growing numbers of blacks, the post-World War II period saw a large increase in automobile use and a growing highway system, which helped whites move out of central cities. This trend may have contributed to the rise in segregation. We shall return to this in the next section.

Regressions of changes in segregation between 1940 and 1970, reported in columns 3 and 4 of table 3 , confirm the continued inportance of black migration in the expansion of the ghetto. For both dissimilarity and isolation, increases in black population are associated with increases in segregation. The coefficients have about the same magnitude as in the earlier period, and again, the effect of 


\section{TABLE 4}

Distribution of Percentage Black in Census Tracts

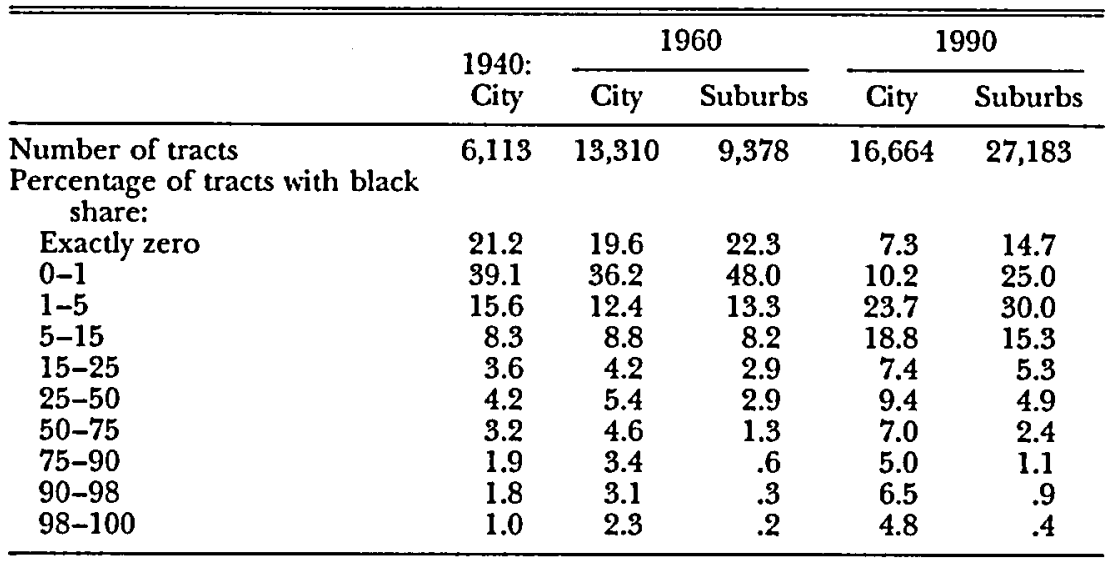

Note.-The sample is census tracts with at least some population.

population change on segregation ceases once the city is highly segregated.

The dramatic clustering of blacks into tracts that were exclusively or nearly exclusively black is particularly striking in this period. Table 4 shows the distribution of census tracts in 1940 and 1960 by the percentage of the tract that is black. ${ }^{11}$ For example, 21 percent of census tracts in 1940 had no blacks and 39 percent were between 0 and 1 percent black. In 1960, the comparable figures were 20 percent and 36 percent-a relatively small change given the massive increase in black population. Between 1940 and 1960, the most remarkable change in racial distribution is the shift from tracts that were moderately black to tracts that were heavily black. The share of central-city tracts that were less than 15 percent black fell, whereas the share of tracts that were 15-90 percent black increased by 4.4 percentage points and the share of tracts that were 90 percent or more black nearly doubled.

By 1970, segregation in America had reached staggering levels. To achieve racial integration in the average MSA, almost 80 percent of the black population would have had to move to a different census tract, and the average black lived in a census tract that was 68 percent black. Isolation of blacks from whites was 41 percent. According to our definition, 127 of 211 MSAs had a ghetto.

"We are not able to distinguish central-city and suburban tracts in 1970 data. Thus table 4 presents data from 1960 instead. 


\section{The Declining Ghetto}

Since 1970 , there has been a decline in segregation. The decline is particularly pronounced in the major cities of the South and West, but segregation has fallen throughout the country. Between 1970 and 1990, both dissimilarity and isolation fell by 17 percentage points. In 1990, only 98 of 313 MSAs meet our definition of a ghetto. Figures 1 and 2 show that the decline in segregation occurs either if we continue to define segregation at the city level or if we use MSA-level indices instead. Figures 3 and 4 show the decline in segregation by region and city size. The reduction in segregation occurred in both big and small cities in all regions of the country.

Table 3 shows that the process driving changes in segregation in the post-1970 period is different from that in the pre-1970 period. Between 1970 and 1990, increases in the black population are associated with increases in isolation but not in dissimilarity. And even for the isolation index, the coefficient on the increase in black population has half the magnitude of the earlier periods. This changirig relationship between black migration and segregation may reflect the fact that the typical black migrant is much more likely to be moving from city to city after 1970 than from rural area to city. The:se urban migrants may have less of a desire to reside in an isolated ghetto.

Further, during the $1970-90$ period, more rapid increases in the nonblack population are associated with a reduction in segregation. This is not true for the earlier periods. It may be that stagnant cities were caught in their historically high levels of segregation, but growing cities could adapt better to declining tastes for segregation.

Integration in the post-1970 period is to a large extent the elimination of areas of MSAs that were exclusively or nearly exclusively white. As table 4 shows, between 1960 and 1990, the share of centralcity tracts that were less than 1 percent black fell from 55 percent to 18 percent and the share of suburban tracts that were less than 1 percent black fell from 70 percent to 40 percent. The share of tracts that were between 1 and 15 percent black, in contrast, rose. It is interesting that reduced segregation is not a product of the integration of all-black neighborhoods. The share of tracts that were at least 90 percent black doubled in both cities and suburbs. ${ }^{12}$

Our estimate of the decline in segregation over the 1970-90 period is somewhat greater than other estimates in the literature (Malssey and Denton 1987, 1993; Farley and Frey 1994). For example,

\footnotetext{
${ }^{12}$ For further documentation of changes in black residential location during this period, see Clark (1979) and Kain (1985).
} 
Massey and Denton (1993) estimate a decline in dissimilarity of 7.5 percentage points from 1970 to 1990 , compared to our 16.7 percentage points. The primary source of difference in these estimates is the set of cities examined. Massey and Denton base their analysis on a smaller set of 30 cities, heavily focused on the older industrial cities of the Northeast and Midwest. As we noted above, segregation in these cities fell by much less than it did elsewhere. When we use the same cities that Massey and Denton examine, we find a decrease in segregation of 10.8 percentage points, so different samples account for the bulk of the difference. Most of the remaining difference is accounted for because we examine segregation of all blacks relative to all nonblacks, whereas Massey and Denton examine segregation of non-Hispanic blacks relative to non-Hispanic whites. Different data samples also help reconcile the smaller differences between our findings and those of Massey and Denton (1987) and Farley and Frey (1994)..$^{13}$

One potential explanation for the decline in segregation over this period is the rise in black incomes and education levels (Smith and Welch 1989). Not only is the timing of this theory somewhat problematic-the greatest economic gains for blacks occurred in the 1950 s and 1960 s - but table 2 also shows that differences in the level of segregation across education levels in 1970 were trivial. If segregation patterns remained at their 1970 levels for each education group and all blacks had moved from being high school dropouts to having at least some college education (a much larger change than the one that actually occurred), segregation would have fallen by only 1.4 percentage points between 1970 and 1990-one-tenth of its actual decline. As table 2 shows, segregation declined within all black education groups.

\section{Segregation across Cities}

The dramatic changes in segregation over time mask a basic fact about segregation suggested by figures 3 and 4: the relative segregation of different cities is very stable over time. The bottom of table 1 shows the correlation of dissimilarity and isolation across cities at different time periods. Even a century apart, dissimilarity is correlated by 50 percent, and isolation is correlated by 14 percent. Over periods of 40-50 years, the correlations range between 30 and 90 percent.

A comparison of the most segregated cities at different points in

${ }^{19}$ In fact, when we use our matched sample, we find the same decline for the 1980 s as Farley and Frey (1994). 
time further illustrates this stability. When the index of dissimilarity is used, Chicago was the most segregated city in 1890, the fourth most segregated city in 1940, the second most segregated MSA in 1970 , and the fourth most segregated MSA in 1990. Cleveland was the second most segregated city in 1890 , the third most segregated city in 1940, the third most segregated MSA in 1970, and the third most segregated MSA in 1990.

To understand the factors associated with different levels of segregation across cities, we relate segregation to several population chatacteristics: the logarithm of the city population, the logarithm of population density, ${ }^{14}$ the share of the population that is black, and the share of the population that is foreign-born or Hispanic. ${ }^{15}$ We also include region dummy variables. City population and density seem natural to control for, given the evidence in figures 3 and 4 . The ethnic composition of the population might be related to segregation because of changes in the desired living status of different groups over time.

Table 5 shows the results of these regressions. Columns 1-4 relate the index of dissimilarity to each of these factors in 1910,1940, 197(1, and 1990. Columns 5-8 repeat the regressions, using the index of isolation as the dependent variable. There is clear evidence that larger or denser cities have higher levels of segregation. In 1910, dissimilarity is related to city density, although isolation is not. In 1940,1970 , and 1990, both measures of segregation are strongly related to population. The coefficients are roughly the same for all three years, although they are somewhat greater in the more recent years than in 1940. These coefficients are large. A one-standarddeviation increase in population increases dissimilarity by about seven percentage points and isolation by about 12 percentage points.

The other independent variables are much less strongly related to segregation. In the later years of the sample, the share of the city that is black is positively related to isolation, although not to dissimilarity. The share of the population that is foreign-born is generally unrelated to segregation, with the exception that in 1990 increases in the Hispanic population are associated with lower segrega-

\footnotetext{
"We measure density as population per acre (before 1940) or square mile. It is not obvious that this is the right measure of density since vacant areas of the city will reduce measured density but not affect the density of the areas in which people actually live. To examine the importance of this, for 1990 we formed an alternative measure of density, using the density of the area inhabited by the average person in the city. Estimates with this measure were little different from estimates with a conventional measure of density, however, so we do not report these results.

${ }^{15}$ We use the population that is foreign-born in 1910 and 1940 and the population that is Hispanic in 1970 and 1990.
} 


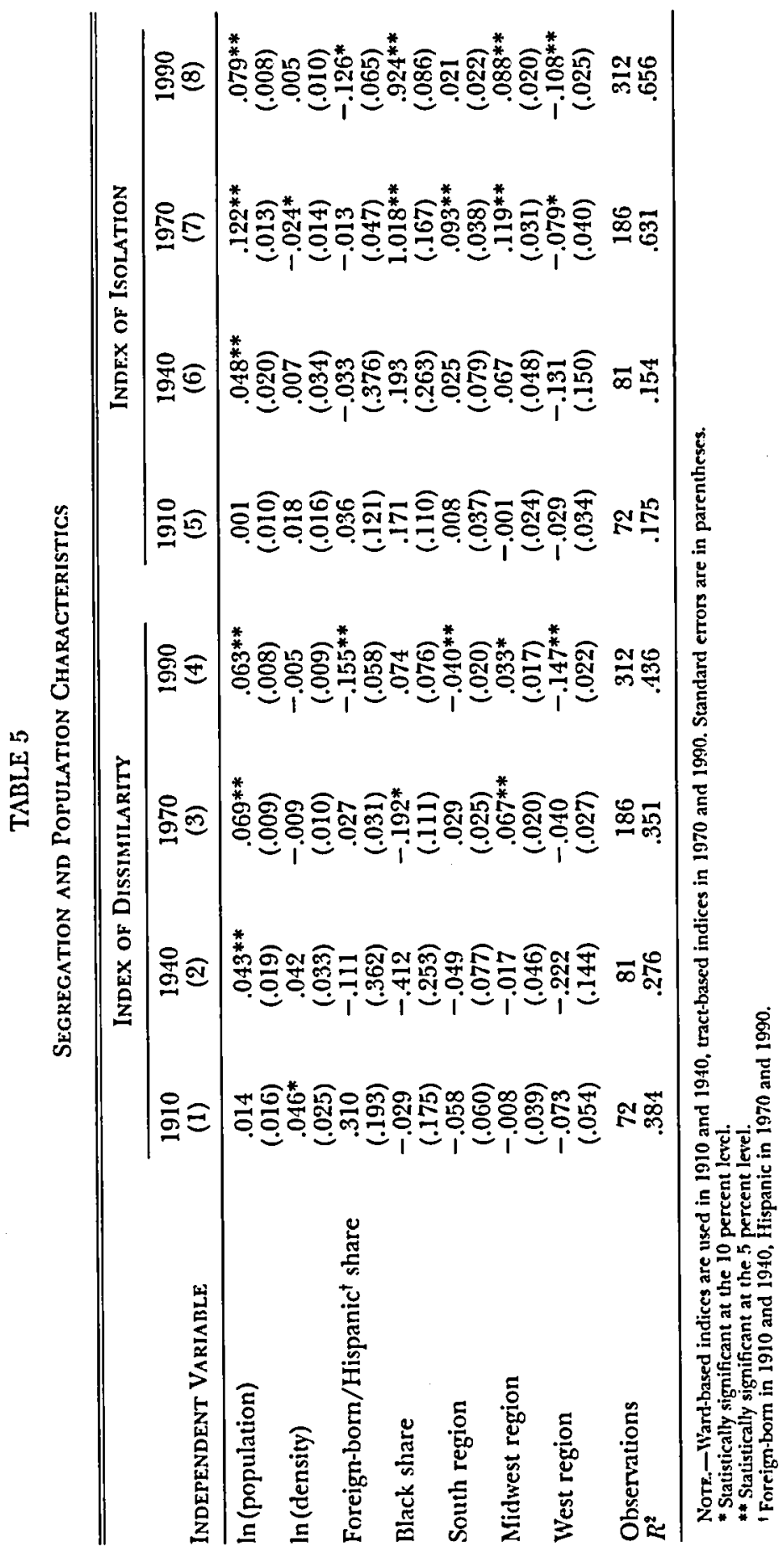


tion. Over time, there are clear regional effects in segregation, but they are not apparent prior to 1970 . The dominant conclusion from table 5 is that segregation is most persistently related to city size. Larger cities are more segregated than smaller cities, and this has been true for most of the last century. We take this as a basic fact about segregation that any model needs to explain.

Since improved transportation may have facilitated the growth of segregation between 1890 and 1970, we examined the correlation between segregation and two measures of transportation costs: the extent of streetcar use in 1902 and highway development between 1950 and 1960. Neither variable was related to segregation at the time (in 1910 and 1970, respectively; see Cutler et al. [1997] for details). ${ }^{16}$

\section{Theories of Segregation}

Having established a basic set of facts about segregation over the past century, we turn now to possible explanations for these phe:nomena. We divide the potential explanations for segregation into three groups.

\section{Ports of Entry}

One explanation for segregation is that ghettos are a mechanism to help a group assimilate into a new environment. Recent migrants cluster with their own group in part to recreate the social milieu and to find the consumer goods of their homeland. This is a typical depiction of immigrant ghettos (e.g., Gans 1962; Glazer and Moynihan 1963), and while there are many differences between the black and the immigrant experience, historical and contemporaneous accounts of black migration from the South to the North often discuss this role of the ghetto (Drake and Cayton 1945; Spear 1967).

Tastes for living among members of one's ethnic group do seem to be particularly strong for recent migrants. In the post- 1970 period for which we have data, black migrants from the South to the North are 10 percent more likely to belong to an all-black church than native northern blacks and 24 percent more likely to prefer a segre:gated neighborhood than lifelong northerners. ${ }^{17}$

${ }^{16}$ We also tested Lieberson's (1980) hypothesis that the employment of blacks as domestic servants at the turn of the century explained low levels of segregation in that period. Contrary to the hypothesis, we found a positive correlation between segregation and the share of blacks working as domestic servants in 1910.

${ }^{17}$ These means are taken from the General Social Survey. The difference between migrants and long-term northerners is robust to adding a variety of education anit age controls. 


\section{Collective Action Racism}

A second theory is that ghettos are a result of collective actions taken by whites to enforce separation from blacks. Collective action may involve specific policy instruments such as racial zoning or restrictive covenants prohibiting sales to blacks, or organized activities such as threatened lynchings or fire bombings that discourage blacks from moving into white neighborhoods. Spear (1967) discusses the role played by the Hyde Park Improvement Protective Club in organizing opposition to integration in Chicago and blacklisting real estate agents who sold to blacks.

These types of collective actions were an important part of urban history. Clark and Perlman (1948) estimate that 80 percent of the deeds in some areas had restrictive covenants. Using a data set of property deeds assembled by Monchow (1928), we find that 68 percent of the 26 deeds in relatively more segregated cities had restrictive covenants whereas only 50 percent of the 25 deeds in relatively less segregated cities had restrictive covenants (the $t$-statistic of this difference is 2.57; see Cutler et al. [1997] for details). So there is some suggestion that differences in segregation are correlated with the presence of legal barriers to black mobility. Indeed, Weaver (1948) and Massey and Denton (1993) argue that these covenants, and other explicit legal barriers, were instrumental in creating ghettos.

\section{Decentralized Racism}

The third theory is that ghettos are maintained by white racism but that segregation is enforced by individual whites' decisions to live with other whites as opposed to collective actions excluding blacks. This type of model is a variant of the "tipping" model introduced by Schelling (1972): because whites are willing to pay more than blacks to live in predominantly white neighborhoods, eventually all neighborhoods become completely segregated even if most people would prefer modest degrees of integration. ${ }^{18}$

Legally, most of the formal barriers to integration have been eradicated. Restrictive covenants were made unenforceable by the Supreme Court in 1948. Government agencies that directly or indi-

${ }^{18}$ Bond and Coulson (1989) integrate the "tipping" and "filtering" models of neighborhood change. Filtering means that as the housing stock in a neighborhood ages, it will pass naturally into the hands of poorer households. Bond and Coulson's model, like the standard tipping models, predicts that any integrated housing market equilibrium will be unstable. 
rectly aided segregation stopped doing so. ${ }^{19}$ But underlying racial preferences may not have changed as much. Thus segregation may still persist at high levels, even with no collective enforcement mechanism.

All these theories are consistent with the relation between city size, black migration, and segregation. For example, there might be fixed costs to erecting formal barriers to integration that whites pay only if the city is sufficiently large or if there are enough blacks to make exclusion worthwhile. Decentralized white racism might be more virulent against relatively less educated southern blacks than against long-term northern blacks. ${ }^{20}$ White racism might also express itself more strongly in dense areas in which blacks are physically closer. The port of entry theory could also generate more segregation in big cities because the possibilities for forming one's own neighborhood may be greater when there are more neighborhoods to choose among.

One way to test among these theories is to look at attitudes toward segregation directly. We do this below, although our data pertain only to the post-1970 period and there may be differences between stated and actual attitudes. A second way to differentiate the theories is to relate segregation to the housing costs of blacks and whites. To see the relationship implied by these theories, we develop a simple model.

\section{Housing Costs and Segregation}

We assume that there are two races ( $W$ and $B$ ), with total populations $N_{W}$ and $N_{B}$, respectively, and two neighborhoods of equal and fixed size (also denoted $W$ and $B$ ). A fraction, $f_{W}$, of the $W$ race lives in the $B$ neighborhood and a fraction, $f_{B}$, of the $B$ race lives in the $W$ neighborhood..$^{21}$ Note that dissimilarity (denoted $S$, for segregation) equals $1-f_{B}-f_{W}$.

Individuals choose neighborhoods to minimize housing and discrimination costs. The psychic discrimination costs are represented by two functions, $D_{W}\left(f_{W}\right)$ and $D_{B}\left(f_{B}\right)$, which are increasing to represent the fact that within each group there is a heterogeneous willingness to live in the other race's neighborhood. Thus the first person

${ }^{19}$ For many years, the Federal Housing Administration used neighborhood racial composition explicitly as a criterion for underwriting mortgage loans. Area; with large black populations were systematically "redlined."

${ }^{20}$ DuBois (1899) suggests that there is a spillover effect in which less skilled blacl: migrants generate a bad image of blacks among whites, which leads to more discrimination against all blacks.

${ }^{21}$ We define the neighborhoods so that both $f_{B}$ and $f_{W}$ are less than one-half. 
to live in the other race's neighborhood will mind it less than the last person to inhabit that area. The function $D_{W}\left(f_{W}\right)$ represents whites' desire to live with other whites and $D_{B}\left(f_{B}\right)$ represents blacks' desire to live with other blacks (the port of entry theory). The $D_{j}\left(f_{j}\right)$ functions (where $j=W, B$ ) are likely to be negative for small values of $f_{j}$ since there will probably be some people for whom the other group's area has some idiosyncratic appeal, such as proximity to work or particular housing characteristics. To capture the centralized racism theory, we assume that blacks also have to pay an added cost, $C$, if they try to live in the white neighborhood. Some part of this cost might appear as higher housing costs paid by blacks in the white area. ${ }^{22}$ We shall test this possibility, but for now we assume that the costs represent nonhousing costs, such as violence. Housing supply is fixed, and the prices in the two areas are denoted $P_{W}$ and $P_{B}{ }^{23}$

As long as $D_{B}(0)+D_{W}(0)+C>0$ (which we assume), members of both races will inhabit both neighborhoods, and the marginal black and white must be indifferent between the two areas. This indifference condition implies that the difference in housing prices between the black and white neighborhoods must equal both the amount of white racism (times negative one) and the sum of the black taste for their own neighborhood plus the costs created by collective action racism, or

$$
C+D_{B}\left(f_{B}\right)=P_{B}-P_{W}=-D_{W}\left(f_{W}\right) \text {. }
$$

In equation (3), either $D_{W}\left(f_{W}\right)$ is negative or $C+D_{B}\left(f_{B}\right)$ is negative. Discrimination causes the neighborhood of one race to have housing costs that are greater than the citywide average and the neighborhood of the other race to have housing costs that are below that average.

If we are interested in inferring the magnitudes of $C, D_{W}\left(f_{W}\right)$, and $D_{B}\left(f_{B}\right)$, one way to estimate these values is to see whether housing costs are higher in areas that are predominantly black than in areas that are predominantly white. If housing quality is roughly constant across neighborhoods, comparing prices in black areas $\left(P_{B}\right)$ to prices in white areas $\left(P_{W}\right)$ will indicate whether $C+D_{B}\left(f_{B}\right)$ or $D_{W}\left(f_{W}\right)$ is positive. For 1970, we shall be able to conduct this test, but in general the data to do this are not available: house price data are generally not linked to the racial composition of the neighborhood.

${ }^{22}$ Empirical evidence suggests that some of this cost may be in the form of higher house prices (e.g., King and Mieszkowski 1973; Yinger 1986).

${ }^{25}$ Allowing an upward-sloping supply of housing in each neighborhood changes the model very little, and a version of the proposition can be proved also assuming flexible supply. 
An alternative test is whether blacks pay more than whites for housing, on average, in the city as a whole (as in Kain and Quigley [1975]). Note that the average house price paid by blacks is $\left(1-f_{B}\right) P_{B}+f_{B} P_{W}$ and the average house price paid by whites is $\left(1-f_{W}\right) P_{W}+f_{W} P_{B}$. Thus the difference in average prices between blacks and whites is $S\left(P_{B}-P_{W}\right)$. If quality is the same throughout the city, we can infer the different costs in black and white neighborhoods from their average costs. The difficulty with this test, however, is adjusting for quality. One might believe that quality is the same within neighborhoods, but comparing housing costs across the city as a whole does not seem reasonable without better quality controls than those in our data. ${ }^{24}$

But there is a third approach to estimating the importance of the different sources of segregation: we consider how the black-white housing price difference varies across cities as the level of segregation varies. If we vary one of the parameters influencing segregation (the cost of centralized white racism [C] or the intercept of one of the discrimination functions $[D(\cdot)])$, the change in average housing costs for blacks relative to whites will be

$$
\frac{d S\left(P_{B}-P_{W}\right)}{d X}=\left(P_{B}-P_{W}\right) \frac{\partial S}{\partial X}+S \frac{\partial\left(P_{B}-P_{W}\right)}{\partial X},
$$

where $X$ is a measure of discrimination ( $C$ or the intercept of one of the discrimination functions). There are two effects in this equation. First, an increase in discrimination induces more blacks to move into the black community and more whites to move into the white community. This will increase or decrease the relative cost of housing for blacks depending on whether house prices are higher or lower in the black community relative to the white community. This effect is shown in the first term after the equal sign.

Changes in discrimination also change the relative demand for the black and white areas. If the increase in discrimination is driven by legal barriers or black tastes for segregated areas, then demand for the black neighborhood will rise by more than the demand for the white neighborhood, and house prices in the black area will rise relative to house prices in the white area. The opposite is true if the

${ }^{24}$ For example, in the 1994 American Housing Survey, there is a mean difference of $\$ 110$ per month in gross rent paid by whites and blacks in the United States as a whole. This difference drops to $\$ 50$ when we control for a basic set of unit-level quality controls. The $\$ 60$ difference accounted for by quality is 9 percent of average black rental payments. The American Housing Survey has many more quality attributes available (square footage, number and type of rooms, leaks, cracks, and so forth) than the census data that we use in our regressions. 
increase in discrimination is driven by increased white discrimination. These changes in the relative demands for the two areas are reflected in the second term after the equal sign.

In general, it is indeterminate how changes in discrimination affect differences in black and white housing costs. In Appendix A, we prove the following proposition.

Proposition. If heterogeneity of tastes within the two groups is sufficiently large (i.e., $D_{W}^{\prime}\left(f_{W}\right)$ and $D_{B}^{\prime}\left(f_{B}\right)$ are large) and if increases in segregation are caused by increases in decentralized white racism, then whites will pay relatively more for housing than blacks as segregation rises. Alternatively, if increases in segregation are caused by increases in collective action racism or by increases in black tastes for their own neighborhood, then blacks will pay relatively more for housing than whites in more segregated cities.

Thus we have a natural test of the explanations for segregation: segregation resulting from centralized white racism or from the desire of blacks to live with other blacks will increase housing costs for blacks relative to whites. Segregation resulting from decentralized white racism, in contrast, will reduce the relative housing costs of blacks compared to those of whites.

We can further differentiate between the centralized white racism hypothesis and the port of entry hypothesis by looking at housing prices for different groups of the black population. The port of entry theory should apply most strongly to new black migrants if they have the strongest tastes for living in their own neighborhood. Thus, if this theory is empirically important, blacks should pay relatively more for housing than whites in more segregated cities, and this should be disproportionately true for black migrants relative to longterm black residents. In the case of centralized white racism, the effect should be the same for all blacks.

The advantage of this test is that it substantially reduces potential problems from unobserved quality relative to tests of mean housing costs alone. Unobservable quality differences will bias our results only if the quality of black relative to white housing is related to the level of segregation in the city. We know of no reason why this should be the case, and when we do observe limited quality measures, we find that including quality measures generally strengthens or does not affect our results. This test also differs from the tests based on average housing costs because it does not estimate the mean values of $C, D_{W}\left(f_{W^{\prime}}\right)$, and $D_{B}\left(f_{B}\right)$. Instead, this test examines which of these variables can best explain the cross-city differences in levels of segregation.

Table 6 summarizes the various predictions of the theories. 
TABLE 6

Predictions of Alternative Theories

\begin{tabular}{|c|c|c|c|}
\hline \multirow[b]{2}{*}{$\begin{array}{l}\text { RELATION BETWEEN } \\
\text { SEGREGATION AND: }\end{array}$} & \multicolumn{3}{|c|}{ TIIEORY } \\
\hline & Port of Entry & $\begin{array}{l}\text { Collective Action } \\
\text { Racism }\end{array}$ & $\begin{array}{l}\text { Decentralized } \\
\text { Racism }\end{array}$ \\
\hline House prices & $\begin{array}{l}\text { Blacks pay more } \\
\text { (esp migrants) }\end{array}$ & Blacks pay more & Whites pay more \\
\hline $\begin{array}{l}\text { Attitudes toward } \\
\text { integration }\end{array}$ & $\begin{array}{l}\text { Blacks prefer seg- } \\
\text { regation (esp. } \\
\text { migrants) }\end{array}$ & $\begin{array}{l}\text { Whites prefer seg- } \\
\text { regation }\end{array}$ & $\begin{array}{l}\text { Whites prefer seE:- } \\
\text { regation }\end{array}$ \\
\hline
\end{tabular}

\section{Explaining Segregation}

In this section, we test the predictions that we just developed.

\section{Evidence on Housing Costs}

We examine house price and rental cost differences using data from the Census Bureau's Integrated Public Use Microdata Samples (IPUMS). For 1940, 1970, and 1990 (no housing cost data exist prior to 1940), we estimate regressions of the form

$$
\begin{aligned}
\ln \text { (housing cost) }= & \alpha_{\text {city }}+\beta_{1} \text { (structural controls) } \\
& +\beta_{2} \cdot \text { black }+\beta_{3} \cdot \text { black } \\
& \cdot(\text { supply and demand controls }) \\
& +\beta_{4} \cdot \text { black } \cdot \text { dissimilarity }+\epsilon,
\end{aligned}
$$

where $\alpha_{\text {city }}$ is a city-specific fixed effect, structural controls include information on the size and quality of the housing unit, and supply and demand controls represent city-level factors controlling for either demand pressures or supply changes. To proxy for demand, we include the growth of the city's population over the previous $\$ 0$ years. Supply factors are available only for 1970 and 1990 and include the share of the housing stock built in the past 30 years, the share of MSA population located in suburban areas, the number of public housing units per capita, and Section 8 rent subsidy payments per capita. ${ }^{25}$

${ }^{25}$ The demand and supply factors by themselves, without the interactions with the black dummy variable, are absorbed by the city fixed effects. Thus only the interactions are included in the regression. Our results are qualitatively unchanged if we replace city fixed effects with a battery of city-level control variables. We have followed the housing literature and not included household characteristics beyond race in our regressions, but none of our results are qualitatively changed if we include age, gender, marital status, income of the householder, or household size. 
The coefficient $\beta_{4}$ represents the differential effect of segregation on blacks relative to whites. From the proposition, $\beta_{4}$ will be positive if differences in segregation are driven by either centralized white racism or black tastes for segregation; $\beta_{4}$ will be negative if variation in segregation is driven by differences in the level of decentralized racism.

We estimate equation (5) separately for owners and renters. Our renter sample, which includes all renter households reporting a positive monthly payment, ranges from 61,180 in 1940 to 193,619 in $1990 .{ }^{26}$ The sample of home owners ranges from 24,724 in 1940 to 369,166 in $1990 .{ }^{27}$

Table 7 shows the results for rental costs (panel A) and home ownership costs (panel B). Columns 1 and 2 report results for 1940 . On average, blacks pay less for both rental and owned housing than whites (47.6 logarithmic points less for rental housing and 63.1 logarithmic points less for owned housing, with the interaction term evaluated at the average segregation level of .719 and population growth at the sample mean of .575). ${ }^{28}$ As noted above, in the absence of better-quality information, we place less weight on the coefficient on the black dummy variable than we otherwise would. Instead, we focus on the fact that as a city becomes more segregated, the relative rental payment for blacks increases compared to that of whites. The coefficients on the interaction term between black and segregation are positive (1.3 in the rental regression and 1.4 in the home owners regression) and statistically significant. Further, they are large; they imply that the bulk of the black-white difference in housing costs disappears as the city approaches perfect segregation. These results cannot be explained by more rapidly growing demand in cities with substantial segregation. As the third row shows, changes in demand disproportionately raise housing costs for whites compared to those for blacks.

This evidence is consistent with both the port of entry theory and

${ }^{26}$ The number of households reporting zero rent ranges from 64 in 1940 to 8,199 in 1970 and 9,520 in 1990. Rent is top-coded at $\$ 1,500$ in 1990. We include a dummy variable indicating top-coded rent in regressions for that year. Excluding the topcoded observations does not influence the results: approximately 500 out of 160,000 households are affected. In 1970 and 1990, we use gross rent, which includes payments for utilities in units in which the resident is responsible for these costs. Gross rent is not available in 1940 .

${ }^{27}$ While there is assuredly some measurement error involved in using self-reported housing values (which are the only housing prices available in the census), work comparing self-reported housing values and transactions prices suggests that reporting errors are not systematically correlated with most variables of interest (e.g., Goodman and Ittner 1992).

${ }^{28}$ These differences decline to 23 logarithmic points for renters and 33 logarithmic points for home owners if we control for other individual-level characteristics. 
the collective action racism theory. We differentiate between the:se two theories by examining how segregation affects housing costs for new migrants relative to older city residents. If ghettos are useful as a port of entry, then recent migrants should pay disproportionately more to live in more segregated areas. If ghettos reflect centralized racism on the part of whites, then all blacks should pay more in more segregated cities. Column 2 reports regressions analogous to tho:se of column 1, where we have interacted the segregation variable with a dummy variable indicating whether the individual is a migrant-which we define as a person who was born in another state. The results show no difference in the effect of segregation on migrant and nonmigrant blacks. The coefficients on the three-way interaction terms between segregation, a migrant dummy, and a black dummy are actually negative (-.246 and -.454) and statistically insignificant. The data thus suggest that variation in the level of segregation in 1940 is due to collective action racism on the part of whites rather than a desire among blacks to live in black areas.

Column 3 of table 7 repeats the specification in column 1 using data for 1970 instead of 1940 . For 1970, we are able to add two MSAlevel supply controls to the regression. Using census data on the year in which each housing unit was built, we calculate the share of housing that was built in the past 30 years. Additionally, we include a measure of suburbanization in each MSA. If new housing or the presence of large quantities of suburban housing alleviates high prices paid by blacks, then these variables will be negatively related to black housing costs. Indeed, increases in housing stock have disproportionately reduced rents for black renters but have not reduced prices for owners. The extent of suburbanization similarly has a negative, though insignificant, effect on black housing costs. Dimand changes over the previous 30 years again have little effect on relative black housing costs.

As the second row shows, the coefficient on the interaction of black and segregation is only one-quarter as large in 1970 as it was in 1940 , and it is not statistically significant for either owners or renters. Since we have data on the structural characteristics of the housing unit in 1970, we can include this information to see how it affects our results. These findings are reported in column 4 of table 7 . Adding structural controls to our regressions does not substantially modify our conclusions: the coefficients on the interaction of black and segrregation increase, but they are still much smaller in 1970 than in $1940 .{ }^{29}$ Thus, by 1970 , collective action on the part of whites was

${ }^{20}$ Since controlling for housing quality makes $\beta_{4}$ greater in 1970 (or less negative in 1990), we have more confidence that omitting housing characteristics in 1940 biases the results against finding a positive estimate of $\beta_{4}$. 


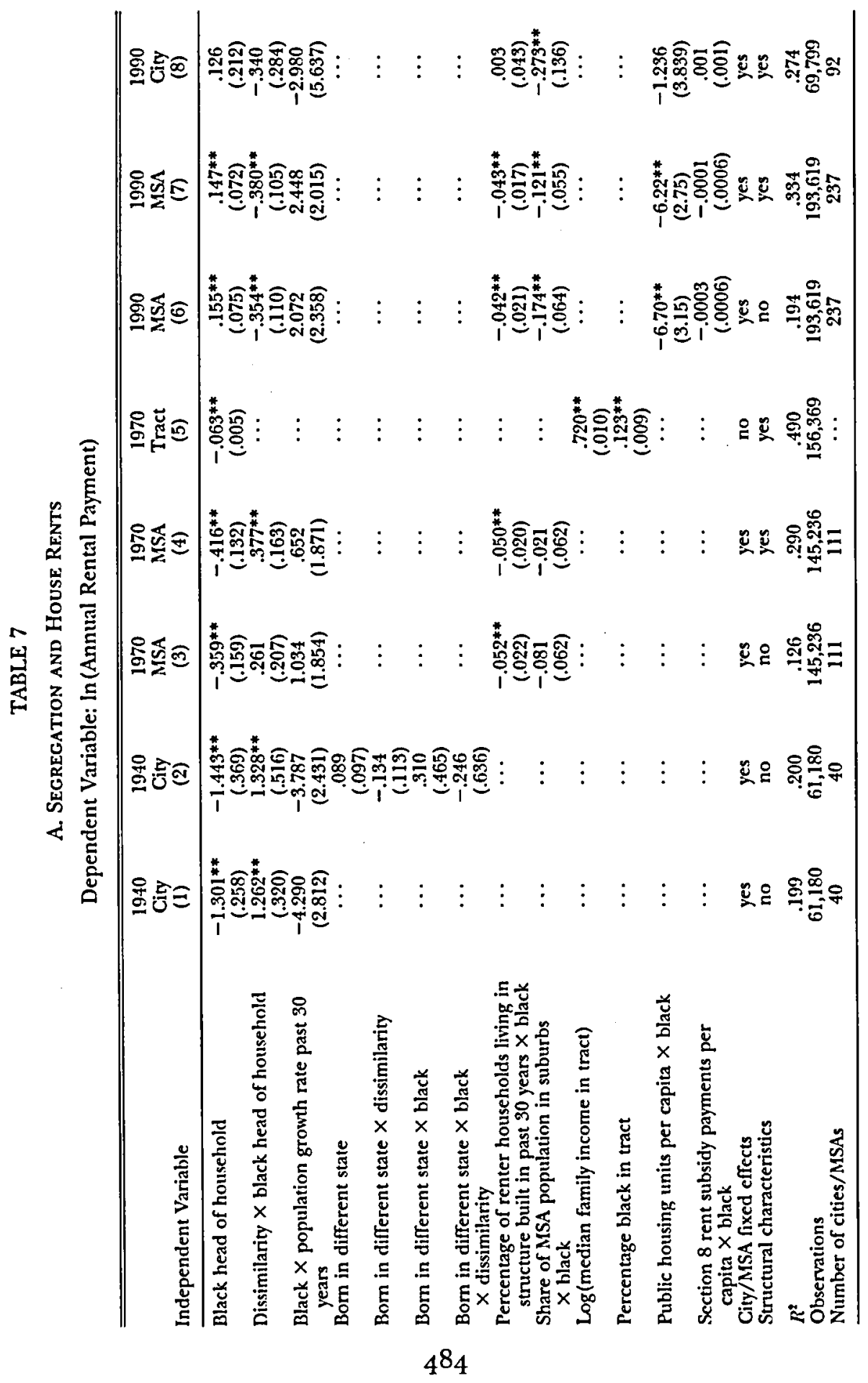


substantially less important in explaining housing costs than it was in 1940. This is true even though segregation rose substantially between 1940 and 1970.

Column 5 presents results using the other test of discrimination: how house prices in predominantly black areas compare to those in less black areas. We can perform this test because the neighborhood sample of the 1970 IPUMS shows characteristics of the individual's census tract, such as percentage black. We thus estimate equations of the form

$$
\begin{aligned}
\ln \text { (housing cost) }= & \alpha+\beta_{1} \text { (structural controls) }+\beta_{2} \\
& \cdot(\text { tract controls })+\beta_{3} \cdot \text { black }+\beta_{4} \\
& \cdot(\text { percentage black in the tract })+\epsilon,
\end{aligned}
$$

where tract controls include the share of the population in the tract that lives in housing built within 30 years and the logarithm of the median family income in the tract. The test of our hypothesis is whether $\beta_{4}$ is greater than or less than zero. ${ }^{30}$ As column 5 shows, housing costs for both owners and renters increase as the percentage black increases. ${ }^{31}$ This fact is consistent with our results in columns 3 and 4 and suggests that, even as late as 1970, segregation was the result of centralized white racism or black desires to live in segregated areas more than decentralized white racism.

Columns 6 and 7 report results for 1990 analogous to columns 3 and 4 for 1970. For 1990, we include two additional supply variables: the number of public housing units per capita and the amount of Section 8 rent subsidy payments per capita. Increased public housing weakly reduces black rental costs relative to those of whites but increases black ownership costs relative to those of whites. New housing lowers relative black rents and increased population growth raises relative black rents. More extensive suburbanization implies lower housing costs for black renters, but not for black owners.

The coefficients on the interaction of black and segregation are strikingly different in 1990 than they are in 1940 or 1970 . Consistent with the decentralized racism model, blacks pay much less than whites in cities with more segregation. The coefficients are between -.3 and -.4 for renters and between -.6 and -.7 for owners. With

${ }^{30}$ The coefficient on $\beta_{3}$ tests whether blacks pay more conditional on neighborhood, which is a test of whether the centralized racism costs $(C)$ are reflected in higher housing costs. We find that $\beta_{3}$ is negative, especially in white neighborhoods. of course, if blacks inhabit lower-quality housing, conditional on neighborhood, this coefficient would be biased downward.

${ }^{31}$ If we omit the other tract-level controls (particularly median income of the tract), the estimate of $\beta_{4}$ is negative. 
and without structural controls, all the coefficients are statistically significant.

The disappearance and reversal of the black segregation premium over time is difficult to disentangle from other important trends affecting housing costs. The period between 1940 and 1990 witnessed the marked decline of northern central-city areas, the rapid emergence of cities in the South and West, and extensive suburban development nationwide. Suburban growth in particular might be responsible for reduced housing demand in the central-city neighborhoods that ghettoized blacks frequently occupy ${ }^{32}$ While we have attempted to control for important supply and demand factors across MSAs, within-MSA variation is more difficult to contend with. ${ }^{33}$ Columrı 8 of table 7 attempts to reduce this variation by examining central-city dwellers exclusively. Sample sizes in these regressions are reduced substantially since only cities with more than 100,000 inhabitants have residents identified in the microdata. Thus, while the point estimate of the black renter segregation premium is consistent with other models, it is not statistically significant. Among black owners, the estimated segregation discount falls substantially but retains its sign. Thus the city-only regressions suggest that within-MSA variation in supply and demand factors can explain at least some of the black segregation discount but does not eliminate it. These factors may include, but are not limited to, decentralized racism.

Our evidence on housing costs thus yields an important conclusion. In midcentury, greater levels of segregation resulted from collective actions on the part of whites to exclude blacks: legitimized forms of discrimination such as restrictive housing covenants and explicit or implicit threats of violence. These factors made blacks pay relatively more for housing in more segregated cities than they otherwise would have. Over the next 30 , and particularly 50 , years, collective action became less important. But racial preferences were not eliminated. By 1990, it appears that differences in residential location between blacks and whites occur because whites' desire to live in white neighborhoods exceeds blacks' desire to live in those neighborhoods. This change has substantially reduced the segregration premium that blacks pay relative to whites, although it has not eliminated the high level of segregation that remains in the United States.

${ }^{32}$ To the extent that this suburbanization represents "white flight" from neighborhoods experiencing racial change, it may still be interpreted as decentralized racism.

${ }^{33}$ Across MSAs, omitted growth factors probably lead us to understate the segregration discount, since included growth predicts lower black housing costs, and segrefgation is negatively correlated with metropolitan growth. 


\section{Evidence on Attitudes toward Integration}

We can corroborate this conclusion to some extent using data on attitudes toward integration. Ideally we would use public opinion data over the past half century to examine trends in attitudes, but publicly available survey data matched to individual location are available only for the post- 1970 period, in the General Social Survey.

To examine the attitude of blacks toward living in integrated areas, we use a question the General Social Survey asked blacks in 1982: "If you could find the housing that you would want and like, would you rather live in a neighborhood that is all black; mostly black; half black, half white; or mostly white?" On average, 67 percent of blacks chose either the third or fourth option. We estimate a linear probability model for blacks preferring to live in a half-white or mostly white ("integrated") neighborhood as a function of segregation in the city. We also control for region, education, sex, and age. Column 1 of table 8 shows that there is no significant relation between segregation and the attitude of blacks toward integration. Indeed, the coefficient on segregation is positive, suggesting that blacks in more segregated cities actually are more likely to desire integration (counter to the port of entry theory), although the coefficient is not statistically significant. ${ }^{34}$

The remaining columns of table 8 show results for three questions about white attitudes toward integration. The first question, asked over the entire time period, inquired whether respondents believed "White people have a right to keep blacks out of their neighborhoods if they want to, and blacks should respect that right." On average, 24 percent of whites believe in the right to segregated housing. As column 2 shows, whites in more segregated cities are more likely to believe in the right to segregated housing. A one-standarddeviation increase in segregation (.129) is associated with a 2.6percentage-point increase in the share of the white population who believe in the right to racially segregated housing. ${ }^{95}$

Column 3 looks at a related question: "Do you think there should be laws against marriages between blacks and whites?" On average, 22 percent of whites support such laws. However, in more segregated

\footnotetext{
${ }^{34}$ If we look at South-North migrants, we do find that these migrants are more likely to prefer segregation. But even within the sample of migrants, this effect is not statistically significant.

${ }^{35}$ We also examined whether faster declines in segregation are associated with more rapidly changing white attitudes (see Cutler et al. 1997). The results show that while there is a significant decline in the answer to this question over time (the coefficient on the time trend is minus one percentage point per year), there is no correlation between the decline in segregation and the change in attitudes across cities.
} 


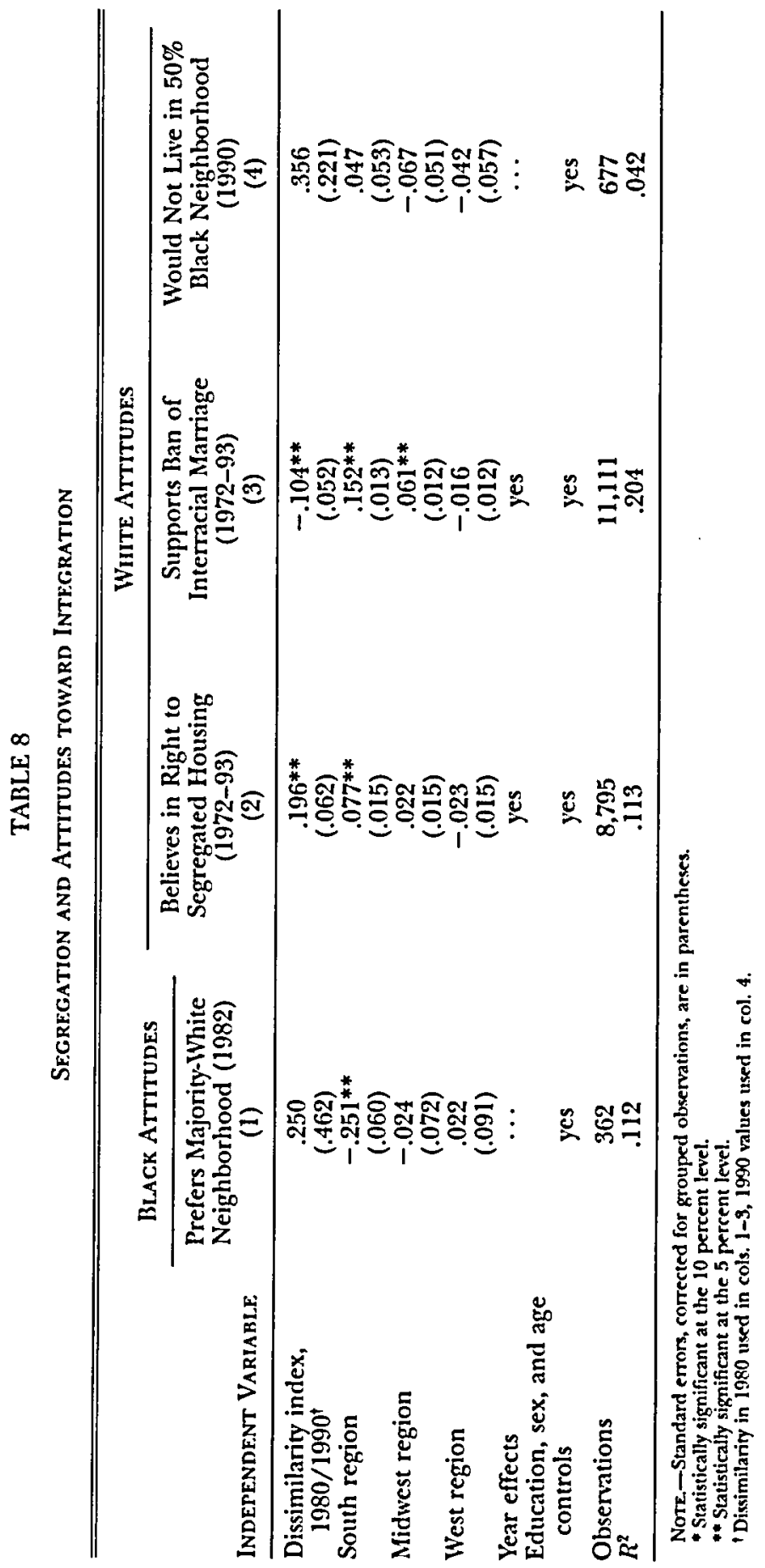


cities, whites are less likely to support a ban on interracial marriage than whites in less segregated cities, which runs counter to the results in column 2.

Column 4 examines a question asked in 1990 only: respondents were asked their support for "living in a neighborhood where half of your neighbors were blacks." Forty-six percent of white respondents registered opposition. In more segregated cities, whites are more likely to oppose living in a majority-black neighborhood, and the coefficient is larger quantitatively than in the previous regressions, although it is not statistically significant. ${ }^{36}$

The survey data are thus generally consistent with the housing price evidence. There is no relation between stated black preferences for segregation and observed levels of segregation, which suggests that, at least in the modern era, segregation is not driven by black tastes for integration. There is a positive relation between segregation and white attitudes toward housing segregation, although this is not true for white attitudes about blacks more generally. In the absence of older data, however, we cannot examine how these results have changed over time.

\section{Case Studies: Cleveland, Atlanta, and Sacramento}

To provide more qualitative evidence on the factors influencing segregation over time, we consider case studies of segregation in three particular cities. We chose cities that are representative of the urban experience over the past century: Cleveland, a typical midwestern city with a ghetto born during the post-World War I period; Atlanta, a southern capital that has historically been segregated but has seen segregation fall substantially in the past two decades; and Sacramento, a rapidly growing western city that has never experienced the segregation of Cleveland or Atlanta, despite having equally rapid increases in the black population. For each city, we gathered census tract data for as long a time as possible: since 1910 in Cleveland, since 1940 in Atlanta, and since 1950 in Sacramento. We then matched census tracts over time so that we could look at changes in segregation for constant physical units (see Cutler et al. [1997] for more details).

${ }^{96} \mathrm{We}$ also found little relation between other measures of racism, such as the stated willingness to vote for a black for president or beliefs about the inherent intelligence of blacks, and the level of segregation, which suggests that discrimination is a multifaceted phenomenon, and only tastes about living near blacks are related to observed levels of segregation. 
Cleveland $^{37}$

Cleveland had a very small black population in 1910. As panel A of table 9 shows, only 2 percent of Cleveland was black in 1910. While blacks in Cleveland were disproportionately concentrated in certain parts of the city (the index of dissimilarity was 66 percent), these areas were not primarily black (the index of isolation was only 8 percent). Historical accounts of Cleveland describe this early period as a relatively golden age of black-white relations and integration in the city.

Cleveland boomed during and after World War I, attracting (and actively recruiting) a large number of blacks from the rural South. Between 1910 and 1940, Cleveland's black population grew by nearly 8 percent annually. With this growth came the institutional framework that would enforce racial barriers. Kusmer (1976) notes that after the first large immigration wave, white resistance to integrated facilities grew. Previously integrated facilities, such as pools, universities, and schools, became segregated. In addition, there is some suggestion that black migrants to Cleveland preferred a more segregated housing structure. One entire church congregation of blacks in Alabama, for example, moved to Cleveland in the 1920s and settled in an all-black area. These two factors led to increased segregation. This shows up in both of our measures of housing segregation: by 1940 , dissimilarity in Cleveland was 84 percent and isolation was 63 percent. At midcentury, segregation in Cleveland appears to be driven by collective actions on the part of whites, with some role from black demand as well. This impression is corroborated by the scattered available data on housing costs. In 1918, the Cleveland Chamber of Commerce estimated that blacks paid 65 percent more than whites for equivalent housing.

Between 1940 and 1970, the Cleveland ghetto grew in physical area. Of the 28 census tracts in the city of Cleveland that reached 25 percent black between 1940 and 1960, 27 were over 75 percent black within two decades of reaching 25 percent black (see table 9 ). Segregation in Cleveland remained high. Between 1940 and 1970, the index of dissimilarity increased from 84 to 87 percent, and the index of isolation rose from 63 to 72 percent. $^{38}$

${ }^{37}$ Moore (1953), Wye (1973), Kusmer (1976), and Galster (1990) all provide historical evidence on this city.

${ }^{38}$ Segregation does not rise much over this period of great black migration. Between 1940 and 1970 , most integrated tracts were integrated only because, as the black ghetto expanded, whites and blacks temporarily lived together as tracts switched from being completely white to being completely black. Therefore, for highly segregated cities, neighborhood change may make integration appear to be higher. 


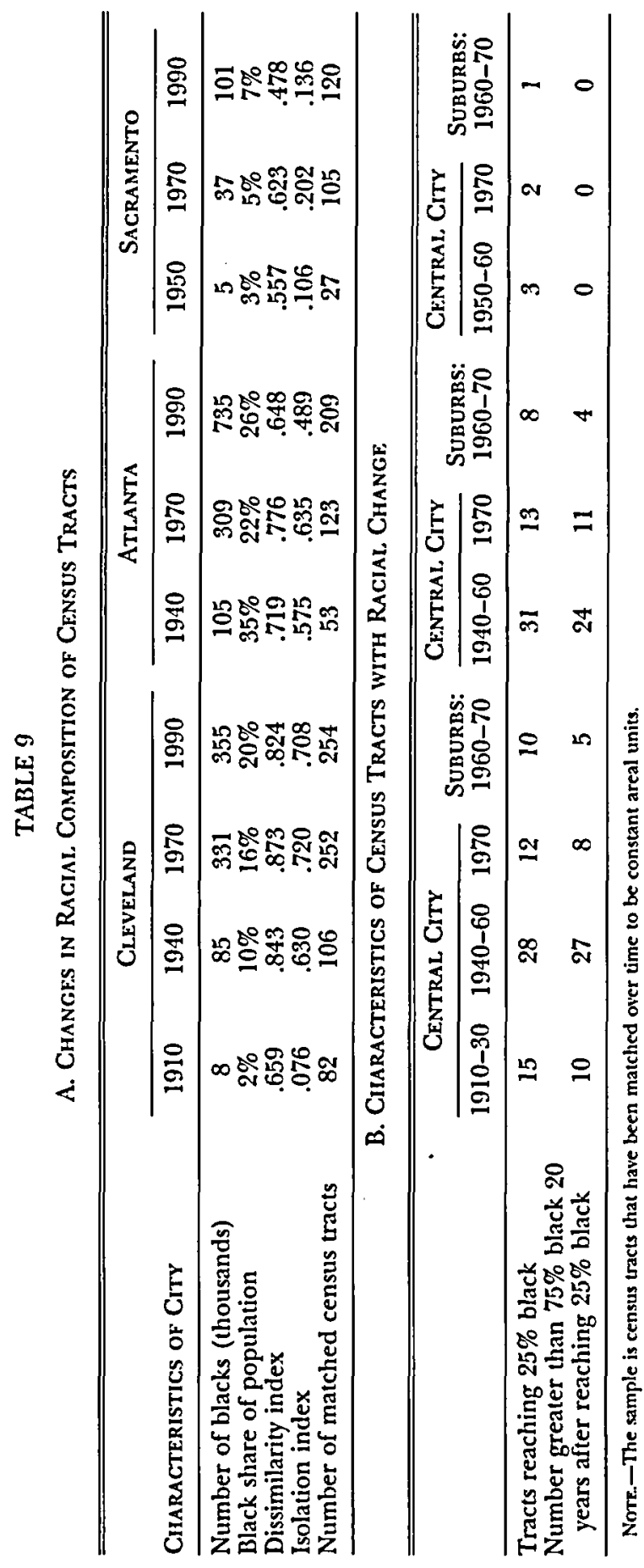


Since 1970, segregation in Cleveland has fallen. Of the 12 city tracts that reached 25 percent black between 1960 and 1970, onethird were less than 75 percent black as of 1990 . Suburbanization has also moderated segregation. Only half of the suburban census tracts that reached 25 percent black in the post-World War II period were over 75 percent black within two decades. ${ }^{39}$ This change in segregation appears to be due to a reduction in the formal mechanisms enforcing segregation. Recent surveys of Cleveland show that whites are not fundamentally opposed to living in integrated areas (Keating 1994). Formal barriers to black mobility, such as restricted covenants, have been reduced or eliminated over the past half century. Where segregation remains, it appears to be propped up by whites' willingness to pay more for mainly white neighborhoods (i.e., decentralized racism).

\section{Atlanta}

The first significant black settlements in Atlanta took place during Reconstruction and consisted of "clusters" around the city's periphery, still apparent today (Kellogg 1977). Facing a rising black population, Atlanta's civic leaders made many attempts to legally enforce residential segregation, particularly after the bloody riot of September 22, 1906 (Crawford 1967). The city explicitly zoned by race in 1913 and 1916; these laws were deemed unconstitutional in 1917. In 1929, the city passed a law forbidding anyone (of either race) from moving into a house on a street in which "the majority of the residences ... are occupied by those with whom said person is forbidden to intermarry" (quoted in Bayor [1996]). This legislation was also deemed unconstitutional. Failing at attempts to zone by race, the city undertook programs of highway development, public housing construction, and slum clearance that displaced many blacks and steered many others to already-crowded black areas. During the urban renewal period of the 1950s and 1960s, critics accused local officials of pursuing a policy of "Negro removal" in their attempts to revitalize the central business district (Bayor 1989).

Thus, even more than Cleveland, Atlanta's history is one of collective enforcement of racial barriers by whites. To a large extent, these efforts were successful. In 1940 (the first year in which census tract data are available), Atlanta was the most segregated of 16 southern

\footnotetext{
${ }^{59}$ The relative integration of suburban tracts does not appear to be an artifact of using census tracts, which may be too large outside of cities to capture the relevant segregation. City-suburb differences in segregation appear for all three case study cities if we use block groups (a significantly smaller geographic unit) rather than tracts to measure segregation.
} 
cities according to both the dissimilarity and isolation indices. Centralized white racism seems clearly to blame.

In the past few decades, however, the city has changed. The Hartsfield administration of the 1940s, 1950s, and 1960s was committed to racial change: the police force was integrated a decade before other southern cities, school desegregation was accomplished easily, and the city termed itself "the City Too Busy to Hate" (Allen 1996; Bayor 1996). Atlanta was a relatively peaceful home for the civil rights movement, and the city elected its first black mayor in 1974 without much incident.

The result was a substantial decline in segregation over the past two decades, particularly in the suburbs. Between 1970 and 1990, the share of blacks living in the suburbs of Atlanta increased from 36 to 56 percent, and the suburbs (with a few exceptions) are much more integrated than the city. Additionally, blacks have been making inroads into previously white areas of the city. Of the 26 census tracts in the metropolitan area that were less than 1 percent black in 1970, only six remained under 5 percent black in 1990. Thus, with the reduction in formal barriers to integration and the active promotion of a racially harmonious society, Atlanta has made great, though incomplete, strides toward integration.

\section{Sacramento}

Sacramento has historically attracted more attention for its Asian and Hispanic populations than for its black residents (Leland 1989). Still, the black population of Sacramento has grown substantially in the post-World War II period, averaging 7.5 percent per year between 1950 and 1990. In 1950, Sacramento's black population was spread unequally (dissimilarity was 56 percent), but blacks were such a small presence even in their main neighborhood that isolation was relatively low (11 percent).

Between 1950 and 1970, urban renewal projects and highway construction dispersed the black population throughout the city. The goal was not particularly to remove blacks, but rather to disperse the poor in general; the city wanted to create a barrier to the further advance of "blighted" areas. Pockets of black residences, each more concentrated than the older neighborhood, developed throughout the city. As a result, both dissimilarity and isolation rose by seven to 10 percentage points.

Despite this increase, segregation in Sacramento remained below that of Cleveland and Atlanta. As table 9 shows, none of the tracts that became 25 percent black between 1950 and 1970 went on to become 75 percent black. In fact, each of these tracts declined in 
black share in the subsequent 20 years as whites moved into these areas. In addition, many tracts that were essentially entirely white in 1970 had a moderate (5-15 percent) share of blacks in 1990.

Several factors likely explain the difference between segregation in Sacramento and that in Cleveland and Atlanta. Sacramento's black population moved to the city in a different time period than either Atlanta's or Cleveland's migrants, and the blacks who came to California were much more likely to be skilled, urban, and northern than the migrants to the older cities. Thus the black demand for segregated areas was probably lower in Sacramento. The city's development also took place in an era in which laws and social norms prevented centralized racism from being a major force. Finally, racist beliefs appear to be less prevalent in the West than in the Midwest or the South, and therefore white demand for segregated areas may have been lower as well.

\section{Lessons from the Case Studies}

While not definitive, our comparison of three representative cities provides support for the empirical patterns we noted above. In Cleveland, segregation was driven by the growth of the black population, both because some blacks desired segregated areas and also because black in-migration sparked racial hatred among whites. Collective action racism also played a substantial role in the formation of the ghetto in Atlanta. Recent years have seen the decline of formal barriers to integration and thus a reduction in segregation. Segregation remains high in many cities, but in areas with more rapid population change, such as Sacramento, patterns of stable integration are developing.

\section{Conclusion}

Our examination of segregation in the past century leaves us with two conclusions. First, the level of segregation in urban America rose for nearly a century and then modestly declined. Segregation in the United States increased continuously from 1890 to 1970 , a period in which ghettos were first born and then cemented themselves in urban life. Since 1970, segregation has been falling. Second, despite these large changes in segregation over time, segregation across cities is very persistent and is strongly related to city size. Larger cities have much higher levels of segregation than smaller cities, and this has been true for most of the last century.

Our qualitative and quantitative evidence suggests that in the midtwentieth century, segregation reflected collective actions on the 
part of whites opposing integration, as opposed to desire for segregation on the part of blacks new to urban America. Restrictive covenants, explicit or implicit threats of violence, and generally adverse social conditions kept blacks out of white areas. Black areas of cities were crowded, and blacks paid more for housing than whites paid in equivalent areas. Over time, formal barriers to integration were eliminated, but discriminatory white tastes remained. Whites still prefer to live with other whites more than blacks prefer to live in white areas. Decentralized racism operating through the price mechanism has replaced centralized, legally enforced racism, and racial differences in housing persist.

The implications of these results for the future are mixed. Segregation has declined over the past 20 years, and this may be related to the elimination of formal barriers to integration. Indeed, the decline in segregation occurred mainly because formerly all-white areas now have small numbers of black residents, which is strongly suggestive of a lowering of walls against black mobility. At the same time, there are more completely black areas in our cities than there have ever been in the past, and large amounts of segregation linger. Possibly, large reductions in segregation will have to await greater change in attitudes toward racial integration than we have experienced in the recent past.

\section{Appendix A}

\section{Proof of Proposition}

We denote $\phi_{W^{\prime}}=N_{W} /\left(N_{W^{\prime}}+N_{B}\right)$ and use the fact that for the housing market to clear it must be true that $\phi_{W} f_{W}=\left(1-\phi_{W}\right) f_{B}$. We also denote $d_{W}$ as the intercept of $D_{W}\left(f_{W}\right)$ and $d_{B}$ as the intercept of $D_{B}\left(f_{B}\right)$. Differentiation of equation (3) yields

$$
\begin{gathered}
\frac{\partial S}{\partial C}=\frac{\partial S}{\partial d_{W}}=\frac{\partial S}{\partial d_{B}}=\frac{1}{\phi_{W} D_{B}^{\prime}\left(f_{B}\right)+\left(1-\phi_{W}\right) D_{W}^{\prime}\left(f_{W}\right)}>0, \\
\frac{\partial\left(P_{B}-P_{W}\right)}{\partial C}=\frac{\partial\left(P_{B}-P_{W}\right)}{\partial d_{B}}=\frac{\left(1-\phi_{W}\right) D_{W}^{\prime}\left(f_{W}\right)}{\phi_{W} D_{B}^{\prime}\left(f_{B}\right)+\left(1-\phi_{W}\right) D_{W}^{\prime}\left(f_{W}\right)}>0,
\end{gathered}
$$

and

$$
\frac{\partial\left(P_{B}-P_{W}\right)}{\partial d_{W}}=\frac{-\phi_{W} D_{B}^{\prime}\left(f_{B}\right) f_{W}}{\phi_{W} D_{B}^{\prime}\left(f_{B}\right)+\left(1-\phi_{W}\right) D_{W}^{\prime}\left(f_{W}\right)}<0 .
$$

Substituting these terms into equation (4) for $X=d_{B}$ or $X=C$ yields

$$
\frac{\partial S\left(P_{B}-P_{W}\right)}{\partial X}=\frac{S\left(1-\phi_{W}\right) D_{W}^{\prime}\left(f_{W}\right)+\left(P_{B}-P_{W}\right)}{\phi_{W} D_{B}^{\prime}\left(f_{B}\right)+\left(1-\phi_{W}\right) D_{W}^{\prime}\left(f_{W}\right)},
$$


which is positive as long as $D_{W}^{\prime}\left(f_{W}\right)$ is sufficiently large. So $C$ and $d_{B}$ will increase the housing cost for blacks relative to that for whites if $D_{W H}^{\prime}\left(f_{W}\right)$ is sufficiently large.

If we use terms (A1) and (A3) and substitute into equation (4) for $X=$ $d_{w}$, we find

$$
\frac{\partial S\left(P_{B}-P_{W}\right)}{\partial d_{W}}=\frac{-S \phi_{W} D_{B}^{\prime}\left(f_{B}\right)+\left(P_{B}-P_{W}\right)}{\phi_{W} D_{B}^{\prime}\left(f_{B}\right)+\left(1-\phi_{W}\right) D_{W}^{\prime}\left(f_{W}\right)},
$$

which is negative as long as $D_{B}^{\prime}\left(f_{B}\right)$ is sufficiently large. Thus as long as there is enough heterogeneity in the white and black populations (so $D_{w}^{\prime}\left(f_{w}\right)$ and $D_{B}^{\prime}\left(f_{B}\right)$ are big enough), it follows that a rise in segregation caused by an increase in $C$ or $d_{B}$ will increase the relative housing costs of blacks, whereas a rise in segregation caused by an increase in $d_{W}$ will increase the relative housing costs of whites.

\section{Appendix B}

\section{Data}

This Appendix describes the data and empirical methods used in this paper. It begins by detailing the creation of our 100-year panel of segregation indices, explaining many of the quality and comparability issues that arise in such a task. The two subsequent sections discuss the sources and methodology involved in the housing rent/value and attitudinal regressions, respectively. The segregation data used in this paper, as well as supplementary data and additional measures of segregation for 1990, are available online at http://www.nber.org/segregation.html. A discussion of the additional measures of segregation can be found in Cutler et al. (1997).

\section{Measuring Segregation, 1890-1990}

The source of our segregation data is the decennial Census of Population. The census reports some form of subcity data for cities above 25,000 in 1890 and above 50,000 in every subsequent year. To ensure at least a minimum number of blacks, our samples include only those cities with at least 1,000 blacks in a given year. The data were gathered by hand for 18901950 and from computer tape after 1950.

Table Al shows characteristics of the sample. From 1890 to 1940, population characteristics are reported by wards. There are several reasons to be cautious about statistics derived from these data. Wards are political units that vary widely in population size and area across cities. In 1910, Philaclelphia's 47 wards, on average, spanned 1,773 acres and contained about 33,000 individuals, whereas Harrisburg's 13 wards averaged 262 acres and about 5,000 inhabitants. Moreover, wards do not always represent geographically compact areas. Detroit's wards comprise thin strips of land perpendicular to the Detroit River. Each ward is only a few blocks wide but extends from the river to the inland city limits. 


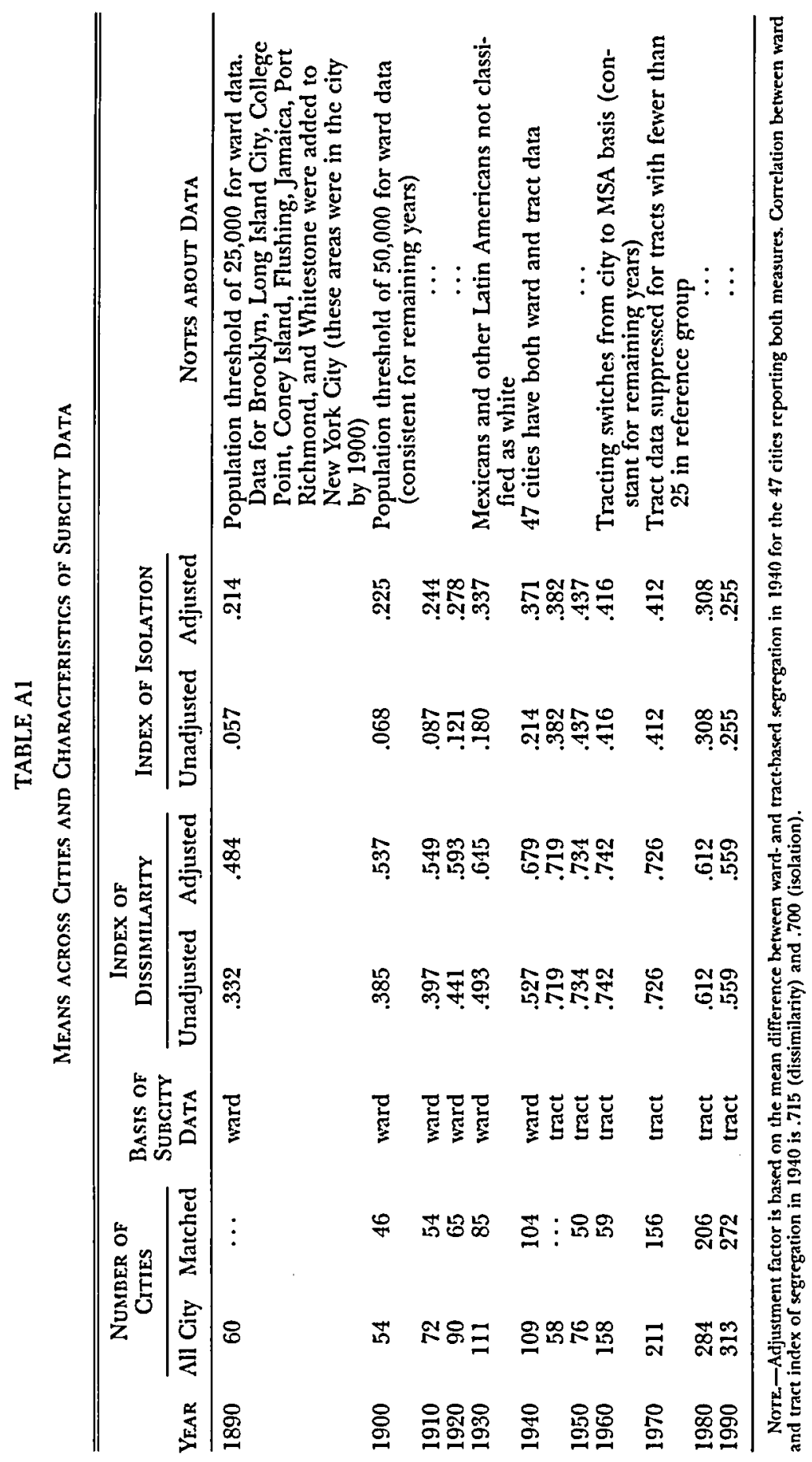


The role of wards as political boundaries may be another cause for concern. City officials wishing to minimize the impact of black voters might draw wards so as to divide the black population evenly among them, creating apparent patterns of racial integration in the data. The black population of Beaumont, Texas, is almost perfectly divided among the city's three wards in 1930 and 1940 (leading to dissimilarity indices on the order of .02), but subsequent tract data reveal a high degree of neighborhood segregation.

From 1940 onward we are able to use census tracts. ${ }^{40}$ Tracts are designed to be geographically compact and socioeconomically homogeneous areas, usually delimited by major streets, city boundaries, or natural features, and they contain approximately 4,000 individuals. This average population size has remained constant through time: tracts are sometimes subdivided or combined to reflect population growth or decline in a given area. Tracts more closely approximate the concept of a "neighborhood" than wards and are more readily comparable across cities and over time.

The existence of both ward and tract data for 47 cities in 1940 allows us to compare measured segregation using both areal units. Since tracts are almost always finer divisions than wards, measured segregation is higher when the tract definition is used. On the basis of census tracts, the average dissimilarity index in these 47 cities was .724 , compared with .577 on the basis of ward data. The tract-based isolation index averages .385 , compared with .284 at the ward level. The measures are highly correlated across cities: .715 for the dissimilarity index and .700 for the isolation index. These values suggest that, in spite of cross-city heterogeneity and other data quality issues, ward-based measures provide a reasonably accurate view of segregation levels.

To enhance the comparability of tract- and ward-based indices, we cmploy a correction factor based on the mean difference between ward and tract segregation in the 47 cities with both measures in 1940. The mean differences are .152 for the index of dissimilarity and .157 for the index: of isolation. Table Al lists the means for both indices over time with and without this correction factor.

In most cities and metropolitan areas, census tracts are relatively constant over time. Occasional shifts in boundaries may occur, and subdivisions of tracts into smaller units are quite common in growing areas. In our three case study cities, we have compiled comprehensive lists of these change: in tracts over time in order to match data at the tract level. As table A2 illustrates, the number of matched tracts always falls short of the total number of tracts in a census year since some tracts must be combined to assure that their boundaries are truly invariant. The only source of growth (or decay) in the number of matched tracts is annexation (or secession) of new territory to the city or metropolitan area. The values in table A2 also reflect some fluctuation resulting when tracts fall to zero population in certain years.

${ }^{40}$ Some cities, primarily in the South and West, do not report ward statistics for 1930 or 1940, presumably because these areas were no longer used for city government. 


\section{TABLE A2}

Tract Matcing in Case Study Cities

\begin{tabular}{|c|c|c|c|c|c|c|}
\hline \multirow[b]{2}{*}{ YEAR } & \multicolumn{2}{|c|}{ Cleveland Tracts } & \multicolumn{2}{|c|}{ AtLanta Tracts } & \multicolumn{2}{|c|}{ SACramento Tracts } \\
\hline & Unmatched & Matched & Unmatched & Matched & Unmatched & Matched \\
\hline 1910 & 109 & 82 & $\ldots$ & $\cdots$ & $\cdots$ & $\ldots$ \\
\hline 1920 & 169 & 100 & $\cdots$ & $\cdots$ & $\cdots$ & $\ldots$ \\
\hline 1930 & 201 & 102 & $\ldots$ & $\ldots$ & $\ldots$ & $\ldots$ \\
\hline 1940 & 206 & 106 & 74 & 53 & $\cdots$ & $\ldots$ \\
\hline 1950 & 206 & 106 & 74 & 53 & 33 & 27 \\
\hline 1960 & 366 & 233 & 179 & 122 & 98 & 77 \\
\hline 1970 & 457 & 252 & 234 & 123 & 172 & 105 \\
\hline 1980 & 499 & 255 & 352 & 184 & 204 & 105 \\
\hline 1990 & 611 & 254 & 477 & 209 & 303 & 120 \\
\hline
\end{tabular}

NoTE.-Counts include only those tracts with population greater than zero in a given year.

Table A2 effectively demonstrates the extent of annexation in the case study cities. Annexation is quite common in other cities as well. Between 1900 and 1930, for example, Los Angeles grew from slightly under 43 square miles to 440 square miles. We use city and metropolitan area boundaries as they existed at the time when measuring segregation. There is some concern that changes in these boundaries might produce changes in measured segregation even if residential patterns have not been altered. For our case study city of Cleveland, we attempt to measure the magnitude of this effect by calculating tract-based indices for 1910-60 using only the 82 tracts that were part of the city in 1910. The effects of annexation amount to slight decreases in both the dissimilarity and isolation indices, but these changes are not particularly large."1

The suburbanization of residence and economic activity through the twentieth century is another concern. In the early part of the time period, our data pertain to cities. As early as 1930 , the Census Bureau began reporting characteristics for areas surrounding major cities. By 1960, the concept of an MSA had been formed, and data for tracts outside of central cities became widely available in that decade and the next. We move from central city-based measures to metropolitan area measures as the data change. We can test for the importance of this for segregation by sampling in the later years for central-city census tracts alone. In 1960, city- and MSAbased dissimilarity measures correlate at .817 , and the difference in means is almost imperceptible (.741 vs. .746). The city and MSA isolation indices correlate even more strongly (.976), with a slightly larger mean difference (.436 vs. .415). The correlation between city and MSA levels of segregation remains high in $1980(.679)$ and $1990(.720)$. Because we think that the

${ }^{41}$ The greatest decrease in the dissimilarity index is .015 and for the isolation index .026 . Cleveland grew in area from 45.6 square miles in 1910 to 73.1 square miles in 1940. 
MSA is a more appropriate notion than the city, we use the MSA measure in our empirical work.

From 1960 to 1990, the number of MSAs in our sample grows from 145 to 313. Many of the new MSAs represent areas previously not considered metropolitan. Others are areas previously contained in a larger MSA that have been separated into their own metropolitan area. Examples include Newark, New Jersey, separated from the New York MSA in 1970, and Oakland, California, separated from the San Francisco MSA in 1990. We treat these areas as new MSAs when their data appear.

In 1970, the census suppresses population counts for areas with under 25 persons. The count of blacks is likewise suppressed for tracts with fever than 25 blacks. To estimate the effect of this on measured segregation, we imposed identical restrictions on the 1990 tract data. The average segregation level in the 313 MSAs increases slightly (.559 to .576 for the dissimilarity index and .255 to .257 for the isolation index) when the restrictions are imposed. The correlation between indices with and without the restrictions is .962 for the dissimilarity index and .9998 for the isolation index. The 1970 measures are therefore probably mild overestimates of true segregation.

Concerns that census tracts are too coarse a division to accurately represent neighborhoods have led some researchers (notably Farley and Frey [1994]) to adopt census block groups as geographical units of choice. Block groups tend to cover about one-fourth the area of census tracts. To examine the effect of using block groups rather than tracts, we computed both (unmatched) tract and block group indices for the three case study cities in 1990. Switching to block groups always results in higher measured segregation. Moreover, the difference is uniformly higher in suburban areas, as predicted by the larger average tract area there. However, these data do not suggest that observed declines in segregation are the result of excessive coarseness at the tract level. When we switch from our sample selection criterion to that employed by Farley and Frey (requiring MSAs to have: a black share of at least 3 percent, or 20,000 blacks), the tract-based decline in dissimilarity from 1980 to 1990 exactly matches the block group-based decline. Just as there are integrated census tracts, there are integrated block groups.

\section{Housing Cost Regressions}

Microdata on housing rents and prices come from the Integrated Public Use Microdata Samples (IPUMS) of 1940, 1970 (15 percent county group sample), and 1990 (1 percent sample). In all three years, we matched individuals to segregation indices on the basis of their metropolitan area of residence. In 1940, tract-based segregation indices exist only at the city level; individuals were assigned the index of the largest city in their metropolitan area.

Rent values in 1940 represent "contract rent," or the actual amount due to the landlord each month. For 1970 and 1990, we use gross rent, which includes payments for utilities if the tenant is responsible for them. A dummy indicating top-coded rent appears in 1990 regressions, where the 
top code was $\$ 1,500$ per month. Price is a self-reported estimate, reported in dollars in 1940 and in ranges thereafter. We set each price equal to the midpoint of the reported range and include a dummy for top-coded prices $(\$ 50,000$ in $1970 ; \$ 400,000$ in 1990) on the right-hand side in each regression.

The regressions reported include no controls for individual characteristics other than race. Additional regressions that controlled for age, sex, marital status, household size, and income showed no significant changes in the reported coefficients. For 1970 and 1990, additional information about the housing unit is available. We include categorical variables for the age and type of the structure. Age categories are less than 1 year old, 2-5 years old, 6-10 years old, 11-20 years old, 21-30 years old, 31-40 years old, 41-50 years old, and over 50 years old. The last three categories are collapsed into one in 1970. Included structure types are mobile home, detached single-family home, attached single-family home, 2-family building, 3-4-family building, 5-9-family building, 10-19-family building, 20-49family building, $50+$-family building, or "other." Most structure type variables are omitted in the 1970 owner regressions since value is reported only for single-family homes.

Supplemental variables, summarized in table A3 along with other regression covariates, come from various sources. Percentage of owner or renter households living in structures built in the past 30 years comes directly from the IPUMS. Public housing units per capita uses housing agency-level data from the Department of Housing and Urban Development (report T18-5, 1994). The number of housing units is accurate as of August 1993. Section 8 rental subsidy payment values aggregate figures reported in the Consolidated Federal Funds Report for fiscal year 1990 . These rent subsidies are paid directly to landlords; thus census respondents should not include them when reporting their monthly rent. Per capita variables are defined using 1990 MSA population.

\section{Measuring Attiludes: The General Social Survey}

To measure attitudinal influences and segregation as well as the effect of segregation on social outcomes, we turned to the General Social Survey. We coded responses into dummy variables as follows. Whites were classified as "unwilling to live in a 50 percent black neighborhood" if they answered "oppose" or "strongly oppose" to "living in a neighborhood where half of your neighbors were blacks" (LIVEBLK, $Q$. 389B). Support of a ban of interracial marriage is revealed directly (RACMAR, Q. 125A). We coded whites as believing in a right to segregated housing if they strongly or slightly agreed with the statement "White people have a right to keep blacks out of their neighborhoods if they want to, and blacks should respect that right"' (RACSEG, Q. 127B).

Blacks were coded as preferring a majority-white neighborhood if they indicated "half black, half white" or "mostly white" rather than "all black" or "mostly black" as their first choice in residential neighborhood composition (RACNEIGH, Q. 142). 


\section{TABLE A3}

Summary Statistics for Regression Covariates

A.

\begin{tabular}{lccc}
\hline \hline Variable & $1910-40$ & $1940-70$ & $1970-90$ \\
\hline Annualized $\Delta \ln$ (black) & .029 & .045 & .023 \\
& $(.022)$ & $(.024)$ & $(.017)$ \\
Annualized $\Delta \ln$ (nonblack) & {$[59]$} & {$[102]$} & {$[203]$} \\
& .014 & .039 & .012 \\
& $(.009)$ & $(.012)$ & $(.015)$ \\
& {$[59]$} & {$[102]$} & {$[203]$} \\
\hline
\end{tabular}

B.

\begin{tabular}{|c|c|c|c|c|}
\hline Variable & 1910 & 1940 & 1970 & 1990 \\
\hline In (population) & $\begin{array}{c}11.972 \\
(.921) \\
{[72]}\end{array}$ & $\begin{array}{c}12.179 \\
(1.007) \\
{[81]}\end{array}$ & $\begin{array}{c}12.881 \\
(.965) \\
{[186]}\end{array}$ & $\begin{array}{l}12.698 \\
(1.001) \\
{[312]}\end{array}$ \\
\hline $\ln$ (density) & $\begin{array}{c}2.399 \\
(.590) \\
{[72]}\end{array}$ & $\begin{array}{l}8.945 \\
(.562) \\
{[81]}\end{array}$ & $\begin{array}{c}5.861 \\
(.982) \\
{[186]}\end{array}$ & $\begin{array}{c}5.642 \\
(.923) \\
{[312]}\end{array}$ \\
\hline Foreigh-born/Hispanic share* & $\begin{array}{l}.189 \\
(.116) \\
{[72]}\end{array}$ & $\begin{array}{l}.099 \\
(.073) \\
{[81]}\end{array}$ & $\begin{array}{c}.070 \\
(.219) \\
{[186]}\end{array}$ & $\begin{array}{c}.067 \\
(.110) \\
{[312]}\end{array}$ \\
\hline Black share & $\begin{array}{l}.103 \\
(.134) \\
{[72]}\end{array}$ & $\begin{array}{l}.105 \\
(.109) \\
{[81]}\end{array}$ & $\begin{array}{l}.101 \\
(.086) \\
{[186]}\end{array}$ & $\begin{array}{c}.105 \\
(.095) \\
{[312]}\end{array}$ \\
\hline Population growth rate, past 30 years & $\cdots$ & $\begin{array}{l}.019 \\
(.013) \\
{[40]}\end{array}$ & $\begin{array}{l}.025 \\
(.017) \\
{[111]}\end{array}$ & $\begin{array}{c}.136 \\
(.120) \\
{[242]}\end{array}$ \\
\hline Share of MSA population in suburbs & $\cdots$ & $\cdots$ & $\begin{array}{c}.600 \\
(.187) \\
{[111]}\end{array}$ & $\begin{array}{c}.647 \\
(.188) \\
{[242]}\end{array}$ \\
\hline $\begin{array}{l}\text { Percentage of renter households living } \\
\text { in structure built in past } 30 \text { years }^{\dagger}\end{array}$ & $\cdots$ & .. & $\begin{array}{c}2.035 \\
(2.192) \\
{[111]}\end{array}$ & $\begin{array}{l}1.987 \\
(1.419) \\
{[242]}\end{array}$ \\
\hline $\begin{array}{l}\text { Percentage of owner households living } \\
\text { in structure built in past } 30 \text { years }{ }^{\dagger}\end{array}$ & $\cdots$ & $\cdots$ & $\begin{array}{c}4.070 \\
(5.938) \\
{[111]}\end{array}$ & $\begin{array}{l}1.832 \\
(1.479) \\
{[242]}\end{array}$ \\
\hline Public housing units per capita & $\cdots$ & $\cdots$ & $\cdots$ & $\begin{array}{c}.005 \\
(.003) \\
{[242]}\end{array}$ \\
\hline $\begin{array}{l}\text { Section } 8 \text { rent subsidy payments per } \\
\text { capita }\end{array}$ & $\cdots$ & $\cdots$ & $\cdots$ & $\begin{array}{r}35.62 \\
(16.86) \\
{[242]}\end{array}$ \\
\hline
\end{tabular}

Note.-Standard deviations are in parentheses. Sample sizes are in brackets.

* Foreign-born in 1910 and 1940 . Hispanic in 1970 and 1990.

These variables are expressed in the form $p /(1-p)$. 
Allen, Frederick. Atlanta Rising: The Invention of an International City, 19461996. Atlanta: Longstreet Press, 1996.

Bayor, Ronald H. "Urban Renewal, Public Housing and the Racial Shaping of Atlanta." J. Policy Hist. 1, no. 4 (1989): 419-39.

. Race and the Shaping of Twentieth-Century Atlanta. Chapel Hill: Univ. North Carolina Press, 1996.

Bell, Wendell. "A Probability Model for the Measurement of Ecological Segregation." Soc. Forces 32 (May 1954): 357-64.

Blau, Peter M. Inequality and Heterogeneity: A Primitive Theory of Social Structure. New York: Free Press, 1977.

Bond, Eric W., and Coulson, N. Edward. "Externalities, Filtering, and Neighborhood Change." J. Urban Econ. 26 (September 1989): 231-49.

Borjas, George J. "Ethnicity, Neighborhoods, and Human-Capital Externalities." A.E.R 85 (June 1995): 365-90.

Case, Anne C., and Katz, Lawrence F. "The Company You Keep: The Effects of Family and Neighborhood on Disadvantaged Youths." Working Paper no. 3705. Cambridge, Mass.: NBER, May 1991.

Clark, Thomas A. Blacks in Suburbs: A National Perspective. New Brunswick, N.J.: Rutgers Univ., Center Urban Policy Res., 1979.

Clark, Thomas C., and Perlman, Philip B. Prejudice and Property: An Historic Brief against Racial Covenants. Washington: Public Affairs Press, 1948.

Crawford, Fred. Civil Aggression and Urban Disorders: Atlanta, Georgia. Atlanta: Emory Univ., Center Res. Soc. Change, 1967.

Cutler, David M., and Glacser, Edward L. "Are Ghettos Good or Bad?" Q.J.E. 112 (August 1997): 827-72.

Cutler, David M.; Glaeser, Edward L.; and Vigdor, Jacob L. "The Rise and Decline of the American Ghetto." Working Paper no. 5881. Cambridge, Mass.: NBER, January 1997.

. "Immigrant Ghettos." Manuscript. Cambridge, Mass.: Harvard Univ., Dept. Econ., 1999.

Drake, St. Clair, and Cayton, Horace R. Black Metropolis: A Study of Negro Life in a Northern Cily. New York: Harcourt Brace, 1945.

DuBois, W. E. Burghardt. The Philadelphia Negro: A Social Study. Philadelphia: Univ. Pennsylvania Press, 1899.

Duncan, Otis Dudley, and Duncan, Beverly. "A Methodological Analysis of Segregation Indexes." American Sociological Rev. 20 (April 1955): 210-17.

Ellen, 1. "Sharing America's Neighborhoods: The Changing Prospects for Stable, Racial Integration." Ph.D. dissertation, Harvard Univ., 1996.

Farley, Reynolds, and Frey, William H. "Changes in the Segregation of Whites from Blacks during the 1980s: Small Steps toward a More Integrated Society." American Sociological Rev. 59 (February 1994): 23-45.

Galster, G. "White Flight from Racially Integrated Neighborhoods in the 1970s: The Cleveland Experience." Urban Studies 27, no. 3 (1990): 38599.

Gans, Herbert J. The Urban Villagers: Group and Class in the Life of ItalianAmericans. New York: Free Press of Glencoe, 1962

Glaeser, Edward L., and Scheinkman, José A. "The Properties of Segregation Measures." Manuscript. Cambridge, Mass.: Harvard Univ., Dept. Econ., 1997.

Glazer, Nathan, and Moynihan, Daniel Patrick. Beyond the Melting Pot: The Negroes, Puerto Ricans, Jews, Italians, and Irish of New York City. Cambridge, Mass.: MIT Press, 1963. 
Goodman, John L., Jr., and Ittner, John B. "The Accuracy of Home Owners' Estimates of House Value." J. Housing Econ. 2 (December 1992): 33957.

Kain, John F. "Black Suburbanization in the Eighties." In American Domeitic Priorities: An Economic Appraisal, edited by John M. Quigley and Daniel L. Rubinfeld. Berkeley: Univ. California Press, 1985.

Kain, John F., and Quigley, John M. Housing Markets and Racial Discrimization: A Microeconomic Analysis. New York: Columbia Univ. Press (for NBER), 1975.

Keating, W. Dennis. The Suburban Racial Dilemma: Housing and Neighborhoods. Philadelphia: Temple Univ. Press, 1994.

Kellogg, John. "Negro Urban Clusters in the Postbellum South." Geografhical Rev. 67 (July 1977): 310-21.

King, A. Thomas, and Mieszkowski, Peter. "Racial Discrimination, Segregation, and the Price of Housing." J.P.E. 81 (May/June 1973): 590606.

Korenman, Sanders; Sjaastad, J.; and Jargowsky, Paul A. "Explaining the Rise of Ghetto Poverty in the 1980s." Manuscript. Minneapolis: Univ. Minnesota, Dept. Econ., 1995.

Kusmer, Kenneth L. A Ghetto Takes Shape: Black Cleveland, 1870-1930. Urbana: Univ. Illinois Press, 1976.

Leland, Dorothy K. A Short History of Sacramento. San Francisco: Lexikos, 1989.

Lemann, Nicholas. The Promised Land: The Great Black Migration and Hou, It Changed America. New York: Knopf, 1991.

Lieberson, Stanley. A Piece of the Pie: Blacks and White Immigrants since 18.80. Berkeley: Univ. California Press, 1980.

Massey, Douglas S., and Denton, Nancy A. "Trends in the Residential Segregation of Blacks, Hispanics, and Asians: 1970-1980." American Sociological Rev. 94 (November 1987): 802-25.

- "The Dimensions of Residential Segregation." Soc. Forces 67 (December 1988): 281-315. (a)

- "Suburbanization and Segregation in U.S. Metropolitan Areas." American J. Sociology 94 (November 1988): 592-626. (b)

- American Apartheid: Segregation and the Making of the Underclass. Cambridge, Mass.: Harvard Univ. Press, 1993.

Monchow, Helen C. The Use of Deed Restrictions in Subdivision Development. Chicago: Inst. Res. Land Econ. and Public Utilities, 1928.

Moore, W. "Status of the Negro in Cleveland." Ph.D. dissertation, Ohio State Univ., 1953.

Myrdal, Gunnar. An American Dilemma: The Negro Problem and Modern Den:ocracy. New York: Harper, 1944.

O'Regan, Katherine M., and Quigley, John M. "Teenage Employment and the Spatial Isolation of Minority and Poverty Households." J. Human Resources 31 (Summer 1996): 692-702.

Osofsky, Gilbert. Harlem: The Making of a Ghetto; Negro New York, 1890-19.30. New York: Harper \& Row, 1966.

Schelling, Thomas C. "A Process of Residential Segregation: Neighborhood Tipping." In Racial Discrimination in Economic Life, edited by Anthony $\mathrm{H}$. Pascal. Lexington, Mass.: Lexington, 1972.

Smith, James P., and Welch, Finis. "Black Economic Progress after Myrdal." J. Econ. Literature 27 (June 1989): 519-64.

Spear, Allan H. Black Chicago: The Making of a Negro Ghetto, 1890-1920. Chicago: Univ. Chicago Press, 1967. 
Taeuber, Karl E., and Taeuber, Alma F. Negroes in Cities: Residential Segregation and Neighborhood Change. Chicago: Aldine, 1965.

Weaver, Robert C. The Negro Ghetto. New York: Harcourt Brace, 1948.

White, Michael J. "Segregation and Diversity Measures in Population Distribution." Popnelation Index 52 (Summer 1986): 198-221.

Wye, C. "Midwest Ghetto: Patterns of Negro Life and Thought in Cleveland, Ohio." Ph.D. dissertation, Kent State Univ., 1973.

Yinger, John. "Measuring Racial Discrimination with Fair Housing Audits: Caught in the Act." A.E.R. 76 (December 1986): 881-93.

- Closed Doors, Opportunities Lost: The Continuing Costs of Housing Discrimination. New York: Sage Found., 1995.

Zunz, Oliver. The Changing Face of Inequality: Urbanization, Industrial Development, and Immigrants in Detroit, 1880-1920. Chicago: Univ. Chicago Press, 1982. 